\title{
44. ON THE NATURE AND CONSEQUENCES OF HYDROTHERMAL CIRCULATION IN THE MIDDLE VALLEY SEDIMENTED RIFT: INFERENCES FROM GEOPHYSICAL AND GEOCHEMICAL OBSERVATIONS, LEG 1391
}

\author{
E.E. Davis ${ }^{2}$ and A.T. Fisher ${ }^{3}$
}

\begin{abstract}
Holes were drilled at four sites in Middle Valley, northern Juan de Fuca Ridge, during Ocean Drilling Program Leg 139 with the goal of characterizing the nature and consequences of hydrothermal circulation and venting in this sedimented rift setting. Four distinct parts of the hydrothermal system were examined, with downhole measurements and shipboard studies reported in the Leg 139 Initial Reports volume and shorebased studies reported in the papers in this volume. These results, particularly those of the geophysical studies, are synthesized herein.

Site 855 is located along a rift-parallel normal fault scarp that bounds the valley. Pore-fluid compositions confirmed that seawater flows into the upper part of the igneous crust along the fault at this site, and heat-flow measurements provided constraints for an estimate of the rate of flow, roughly $0.5 \mathrm{~m} / \mathrm{yr}$.

Site 857 is situated where the crust is covered by a $470-\mathrm{m}$-thick sequence of turbidite sediments. The concept of a permeable "hydrothermal basement" reservoir was confirmed at this site; measured and inferred permeabilities demonstrated that the sediment section is relatively impermeable (nominally $10^{-16}$ to $10^{-17} \mathrm{~m}^{2}$ ) and serves to inhibit vertical advective heat transport, whereas the section below the sediment seal is sufficiently permeable (bulk permeability possibly as high as $10^{-12} \mathrm{~m}^{2}$ ) to support vigorous pore-fluid convection. This permeable hydrothermal basement reservoir comprises a highly altered sequence of interbedded basaltic sills and turbidite sediments. The nearly complete loss of potassium from the sediments, together with the current composition of pore fluids, suggests a minimum water:rock mass ratio in the reservoir of about 50 .

At Site 858, a suite of holes was drilled in and immediately adjacent to a hydrothermal vent field, where fluids ascend through the locally attenuated section of sediment above a small basement edifice. Temperature measurements in the holes located adjacent to the field indicate that upflow is confined to the zone directly beneath the vent field. Rates of fluid flow through the sediment section less than $100 \mathrm{~m}$ from the vent field appear to be thermally insignificant as a result of the low permeabilities characteristic of the sediment surrounding the upflow zone. As within hydrothermal basement at Site 857, sediment alteration is accompanied by large physical changes. Seismic velocities increase and porosities decrease systematically with progressive degrees of alteration (well defined by observations at all sites), commonly reaching values of $3000-4000 \mathrm{~m} / \mathrm{s}$ and $20 \%-30 \%$, respectively, and over $5000 \mathrm{~m} / \mathrm{s}$ and less than $10 \%$ in extreme cases. The strength gained by the sediment through extreme hydrothermal alteration allows fracture permeability to be supported, and hence fluid flow to be promoted.

Efficient hydrologic interconnection between the vent field at Site 858 and hydrothermal basement at Site 857 , roughly $2 \mathrm{~km}$ away, is suggested by observations and estimates of temperatures, water compositions, alteration assemblages, and formation pressures at both sites. The pressure gradient responsible for the fluid flow beneath and through the vent field is inferred to arise from the simple chimney effect of the hot, low-density fluids in the permeable basement edifice and overlying plug of altered sediment which are hydrologically isolated from the surrounding low-permeability sediments. Despite the probable long history of hydrothermal circulation and discharge at Sites 857 and 858, temperatures appear never to have exceeded significantly the present-day temperature of about $280^{\circ} \mathrm{C}$. This is suggested by the alteration assemblages at both sites, by fluid inclusion temperatures determined for minerals precipitated in the upflow zone, and by the lack of significant accumulations of high-temperature $\left(>350^{\circ} \mathrm{C}\right)$ hydrothermal mineral deposits in or beneath the vent field. It appears that spatial and temporal variations in heat supply have not resulted in large temperature variations, possibly because of the buffering effects of the large and efficiently mixed upper-crustal reservoir, and that on average the supply of heat has not been sufficient to raise temperatures in the reservoir to above about $300^{\circ} \mathrm{C}$.

This contrasts with the situation at Site 856, where holes were drilled in a transect crossing a large, relic massive sulfide deposit. A suspected genetic relationship between the deposit and an adjacent laccolithic intrusion was invalidated by stratigraphic and structural observations. Simple mass- and heat-balance calculations, based on estimates of the composition and size $\left(>10^{9} \mathrm{~kg}\right)$ of the deposit and of the composition and temperature of the fluid $\left(\mathrm{c} .400^{\circ} \mathrm{C}\right)$, do not preclude formation of the deposit by fluids from a local reaction zone of hot rock or magma, however. A volume of less than $1 \mathrm{~km}^{3}$ of such hot rock or magma would be sufficient to supply the heat; a remote or regional source is not required. Although a reaction zone was not penetrated at this site, the composition of the massive sulfide provides information about the source of hydrothermal fluids. A mixture of fluid that reacted with purely igneous rock at high temperature $\left(\right.$ c. $\left.400^{\circ} \mathrm{C}\right)$, and fluid that reacted with sediments at a lower temperature is suggested. This mixture may have resulted from the local high-temperature reaction zone having been fed by the regional hydrothermal basement reservoir characterized by Site 857 .
\end{abstract}

\footnotetext{
${ }^{1}$ Mottl, M.J., Davis, E.E., Fisher, A.T., and Slack, J.F. (Eds.), 1994. Proc. ODP, Sci. Results, 139: College Station, TX (Ocean Drilling Program).

${ }^{2}$ Pacific Geoscience Centre, Geological Survey of Canada, P.O. Box 6000, Sidney, B.C., V8L 4B2, Canada.

${ }^{3}$ Department of Geological Sciences and Indiana Geological Survey, Indiana University, 611 North Walnut Grove, Bloomington, IN, 47405-2862, U.S.A
}

\section{INTRODUCTION}

\section{Objectives}

A working model for hydrothermal circulation in sediment-filled rift valleys that has been proposed and evaluated by numerous investigators is shown in Figure 1. This model served as the paradigm to be tested by drilling during Ocean Drilling Program (ODP) Leg 139. Several elements are key to this model, and although not all were unequivocally confirmed or well constrained by the drilling results, a great deal was learned about them. One of the most fundamental 
A
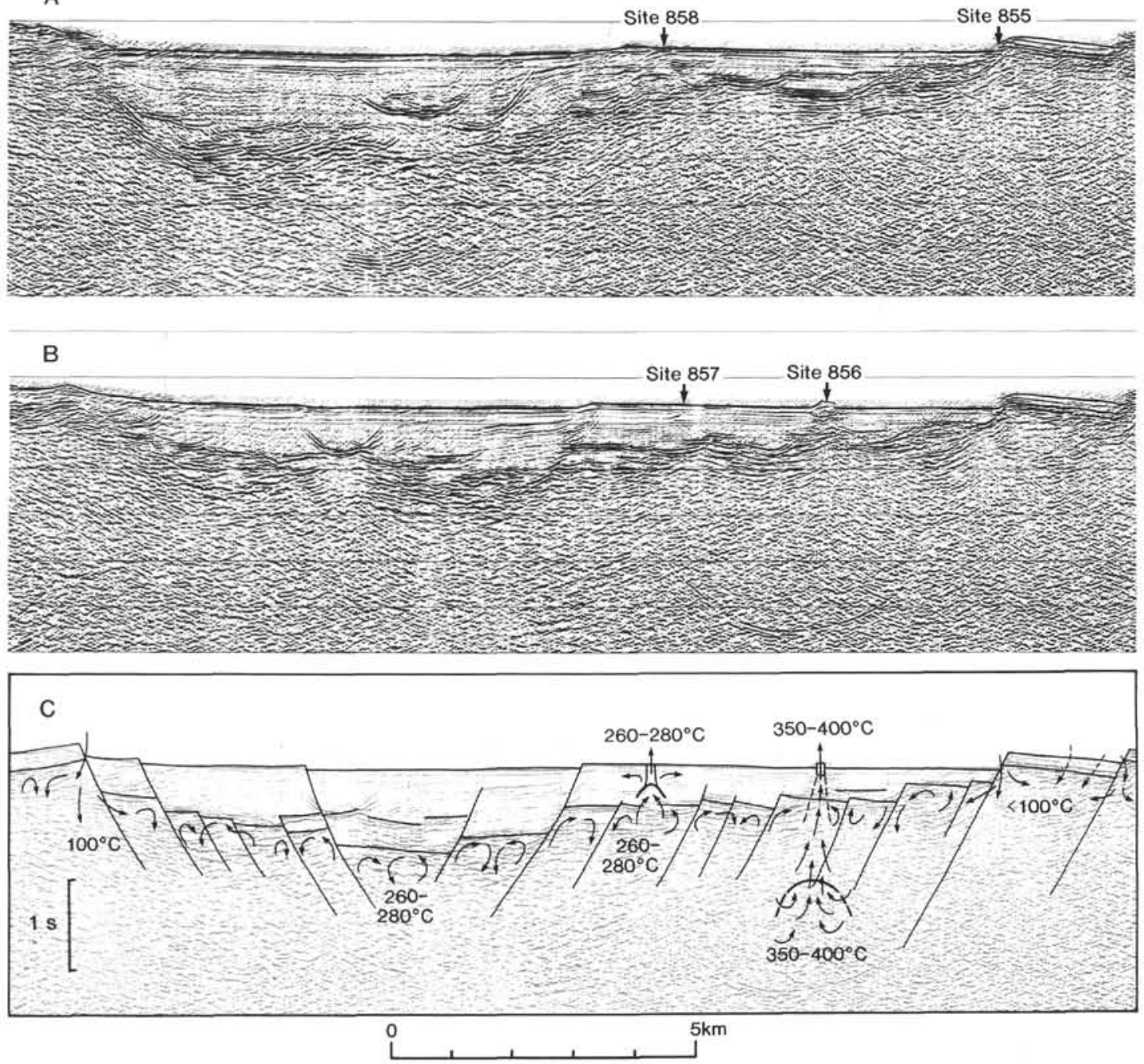

Figure 1. A. and B. Seismic reflection profiles crossing Middle Valley and Leg 139 drilling Sites 855-858 (Davis, Mottl, Fisher, et al., 1992; Rohr et al., 1992). Line locations are shown in Figures 3B and 3C. C. Conceptual cartoon of hydrothermal circulation in the Middle Valley sedimented rift, based on inferences from seafloor heat-flow measurements, seismic reflection profiles, and results of Leg 139 drilling.

elements of the model, most vigorously debated, and most difficult to characterize, is the presence of a hydrothermal fluid reservoir and reaction zone, consisting of a hypothesized permeable region in the upper oceanic crust that is bounded below by less permeable igneous rocks, and above by sediments. Because of their low permeability, sediments limit the fluid flux and advective transport of heat through the seafloor, and because of their relatively low thermal conductivity, they insulate the crust. Both factors, and particularly the first, cause crustal temperatures at shallow depths to be maintained at generally much higher values than those typical in unsedimented ridge-crest environments. In sedimented areas, the combination of heat flow and seismic reflection observations show a general inverse correlation between heat flow and the local thickness of the sediment column, both in ridge-crest (e.g., Davis and Lister, 1977; Davis and Villinger, 1992) and ridge-flank environments (Davis et al., 1989; 1992). This has led to the concep, of a permeable hydrothermal basement reservoir, in which temperatures are homogenized by vigorous hydrothermal circulation. Fluid flux through the seafloor and formation of associated metal-sulfide deposits are thought to be limited to sites where high-permeability pathways breach the sediment column. Recharge is inferred to be distributed regionally within or outside the bounds of the valley, and/or along rift-parallel normal faults.
Objectives of ODP Leg 139 were directed toward testing and refining this model, and better constraining the chemical and physical processes involved as seawater invades the crust, interacts with the sediments and igneous rocks at various temperatures along its path, and escapes at sites of focused discharge and hydrothermal mineralization. Toward these ends, drilling sites were located in what were inferred to be four distinct hydrologic environments within the Middle Valley rift, including an area of seawater recharge close to one of the rift-bounding normal faults, an area where permeable basement is well sealed by sediment, an area of current focused discharge, and a site where relic hydrothermal discharge had produced a large massive sulfide deposit.

\section{Setting}

Middle Valley is situated near the intersection of the Juan de Fuca Ridge and the Sovanco transform fault zone, and is filled with up to 2 $\mathrm{km}$ of Pleistocene turbidite sediments shed from abundant glacial sources in the Coast Range of British Columbia through Queen Charlotte Sound (Fig. 2). Details of the tectonic and thermal structure of the rift are discussed in Davis and Villinger (1992) and references therein. The valley lies roughly along strike from the axis of the volcanically 


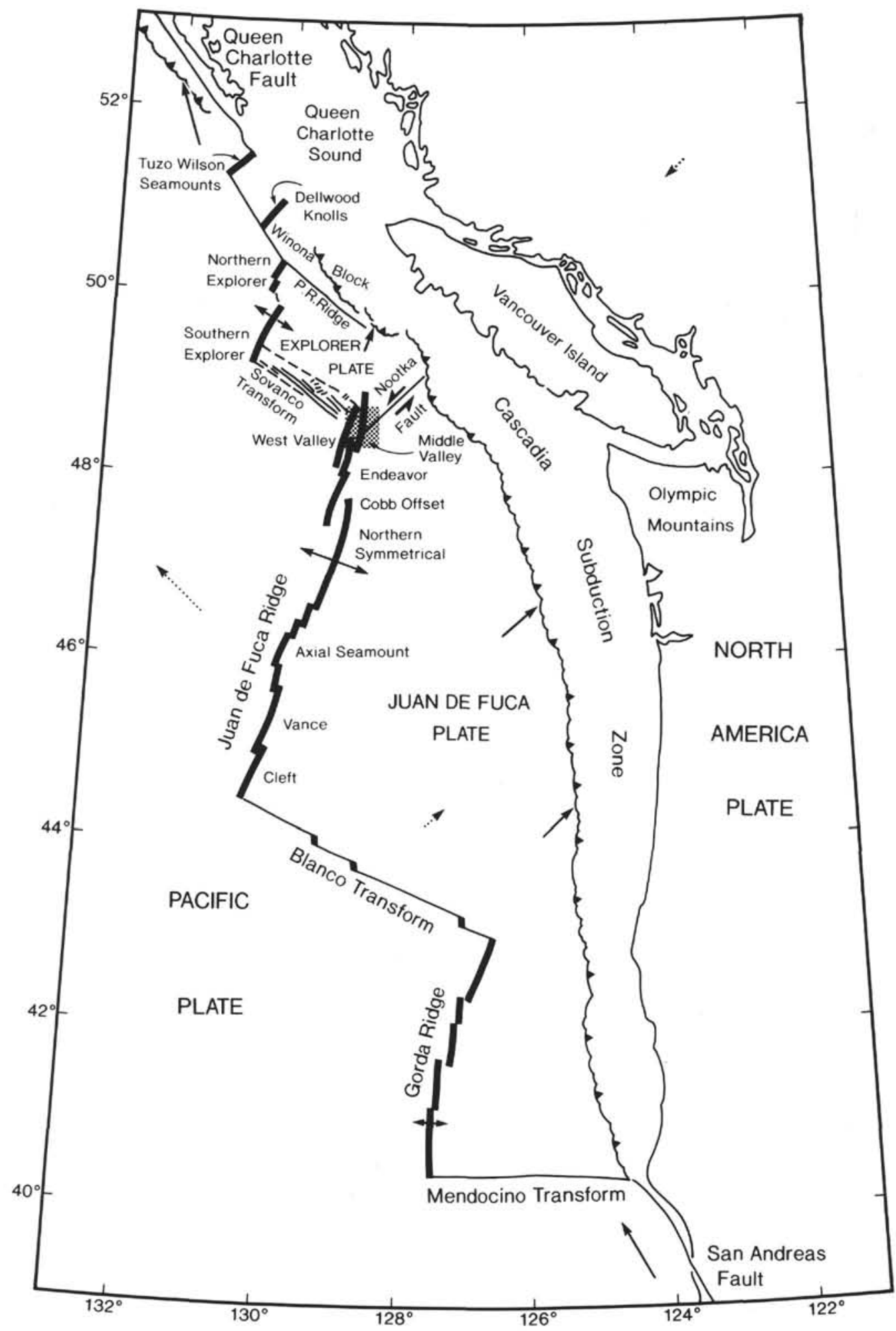

Figure 2. Schematic map of the Juan de Fuca Ridge system, showing local tectonic plates and plate boundaries including the primary segments of the Juan de Fuca Ridge, and relative (solid arrows) and absolute (dashed arrows) plate-motion directions. The area over Middle Valley shown in Figures 3B and 3C is stippled.

robust Endeavour ridge segment and until recently has been the primary locus of spreading. Much of the current extension of the northernmost Juan de Fuca Ridge is probably taking place in an adjacent rift, West Valley, situated $15 \mathrm{~km}$ west of Middle Valley. The partitioning of extension between the two rifts is not well constrained, although the non-central position of Middle Valley in the Brunhes magnetic anomaly suggests that Middle Valley has been offset to the east by several kilometers of extension in West Valley. This makes the age of the crust beneath the Middle Valley rift difficult to assess; isochrons presented here are derived from distances to the eastern Brunhes/ Matuyama magnetic boundary, and the spreading rate of the ridge defined further to the south where the seafloor spreading magnetic 
anomaly pattern is symmetrical and complete ${ }^{4}$ (Currie and Davis, this volume; Davis and Currie, 1993). On this basis, ages beneath the drill sites in the eastern part of the valley are estimated to range from about 350 to $550 \mathrm{ka}$.

The most fundamental elements of Middle Valley are revealed by bathymetry and side-scan acoustic imagery (Figs. 3 and 4). Largeoffset normal faults form the eastern and western boundaries of the valley. Evidence for faults with minor offset (less than $10 \mathrm{~m}$ ) on the generally flat and smooth sedimented valley floor is seen in both the bathymetric and acoustic image data. These offsets probably have accumulated during the Holocene, when rates of turbidite sedimentation were relatively low. Also seen in the data is clear evidence for intrusive and extrusive magmatism, hydrothermal activity, and erosion, much of which probably also developed during the Holocene.

Leg 139 drilling sites are located in the southeastern part of Middle Valley, outside the deepest part of the rift. The sites are on a tilted fault block, the western part of which is topographically uplifted roughly $100 \mathrm{~m}$ above the floor of the rift axis. Sites were selected over clearly defined targets where sediment thickness was not excessive and drilling objectives could be reached. Detailed descriptions of each site, along with discussions of shipboard scientific results, are included in Davis, Mottl, Fisher, et al. (1992). Results of post-cruise studies are described in the various papers in this volume, and a broad overview is provided herein.

\section{SITE DESCRIPTIONS AND SUMMARY OF RESULTS Site 855-Fluid Recharge}

Site 855 is located along the normal fault that bounds the valley on its eastern side (Figs. 1, 3-6). Local throw on the fault, $115 \mathrm{~m}$, exceeds the sediment thickness on the footwall block, estimated from seismic reflection data to be about $100 \mathrm{~m}$, and thus the upper igneous crust is probably exposed along the base of the scarp. The site is furthest from the axis of the valley, and the crustal age is estimated to be $550 \mathrm{ka}$ (Fig. 4). Four holes were drilled into the hangingwall block to form a transect normal to the fault scarp (Figs. 5 and 6). Holes $855 \mathrm{~A}$ and $855 \mathrm{~B}$, drilled approximately $70 \mathrm{~m}$ and $40 \mathrm{~m}$ from the base of the fault scarp, intersected igneous rocks in what is probably the footwall of the fault at depths of 74 and $45 \mathrm{mbsf}$, respectively, which constrains the dip of the normal fault to be between $45^{\circ}$ and $50^{\circ}$. This dip, although shallow relative to that expected for the surface outcrop of a normal fault, is in good agreement with the dip of the fault scarp estimated using the height of the fault scarp and the width determined from acoustic image data (Shipboard Scientific Party, 1992a). Igneous rocks recovered from Holes $855 \mathrm{C}$ and $855 \mathrm{D}$ were inferred to be from the hangingwall, as the thickness of the sediment section there (roughly $100 \mathrm{~m}$ ) agrees well with that estimated from seismic reflection data on the footwall block (Fig. 6). This close match requires rapid vertical movement on the fault relative to sedimentation (i.e., during the last tens of thousands of years). An alternate possibility is that the fault has been active over a much longer period of time, that the sediment thickness on the hangingwall is considerably greater than that on the uplifted footwall, and that the igneous rocks drilled in Holes 855C and 855D are from the footwall as in Holes 855A and 855B (see Rohr and Schmidt, this volume). The general match of the seismic structure across the fault at Site 855 (Fig. 6), and the lack of fanned (syntectonic) or flat-lying (post-tilt) sediments on the footwall block (Davis and Villinger, 1992) strongly favor the former interpretation, that the throw on the fault, the footwall rotation, and the exposure of basement along the scarp are more recent than the local accumulation of sediment.

\footnotetext{
${ }^{4}$ Ages adopted here differ slightly from those estimated in Davis, Mottl, Fisher, et al., 1992, as a result of the use of the revised time scale of Spell and McDougall, 1992.
}

Poor drilling conditions in igneous basement at Site 855 prevailed in all holes and limited penetration to only a few meters. Basement rocks recovered are extrusive and of typical mid-ocean ridge basalt composition like the rocks of the nearby Endeavour segment of the Juan de Fuca Ridge (Shipboard Scientific Party, 1992c). Alteration of the basement rocks and overlying sediments is minor, indicating that the rocks were quenched at the seafloor upon eruption and had never been exposed to high-temperature hydrothermal fluids for any significant period of time. The basement rocks are strongly magnetized at a level averaging roughly $10 \mathrm{~A} / \mathrm{m}$. On the basis of magnetic modelling, Currie and Davis (this volume) infer that this level of magnetization must persist through a section with a cumulative thickness of several hundred meters in order to produce the locally strong positive magnetic anomaly observed at the sea surface. Thus it appears that at this location the crust was produced in a relatively sediment-free environment, prior to the formation of the deep extensional rift now present to the west. The boundary between normally magnetized (extrusive) and non-magnetized (intrusive, highly altered) crust lies several kilometers west of Site 855 and the fault along which this site is located. If sediment accumulation followed formation of the crust at this site, creation of a hydrologic barrier to crustal fluid recharge and discharge probably occurred after the crustal section was well cooled. Temperatures in the upper crust rose during sedimentation, however; the level of hydrocarbon maturity at Site 855 indicates that temperatures reached at least $50^{\circ} \mathrm{C}$ at the base of the section (Shipboard Scientific Party, 1992a; Simoneit, this volume) at some point during burial. The conductive heat flow though the section would have been at least $500-600 \mathrm{~mW} / \mathrm{m}^{2}$ at that time (depending on the sediment thickness), similar to the present-day level observed several hundred meters west of the fault (Davis and Villinger, 1992).

Temperature measurements made at Site 855 (Shipboard Scientific Party, 1992a) indicate that the heat flow near the scarp (roughly 350 $\mathrm{mW} / \mathrm{m}^{2}$ ) is now lower than that a few hundred meters away, and that the temperature at the base of the sediment section, about $33^{\circ} \mathrm{C}$, may be cooler than it was in the past (Shipboard Scientific Party, 1992a). On the basis of these observations, it was concluded that at this location, the exposure of permeable basement along the fault scarp now serves as a "line-source" for seawater recharge. This same conclusion was reached from the composition of pore fluids in the basal sediments (Shipboard Scientific Party, 1992a), and from the nature of carbon in kerogens that indicates the presence of cold, oxygenated seawater (Whelan et al., this volume). Sediment porewater compositions in the upper tens of meters reveal a typical diffusional chlorinity profile, which suggests that recharge is predominantly through the basement outcrop, and that water is not drawn down through the sediment section (Shipboard Scientific Party, 1992a).

Direct evidence for fluid recharge was not clearly observed in any of the site-survey heat-flow measurements collected along the fault. Anomalously high heat flow indicated that hydrothermal discharge may occur in a few discrete locations, although these instances are relatively rare. Along most of the fault where measurements were made, heat flow is remarkably constant, about $580 \mathrm{~mW} / \mathrm{m}^{2}$, at the distances from the fault of a few hundred meters that most measurements were made (Davis and Villinger, 1992). That the heat-flow anomaly associated with fluid recharge appears to be limited to a scale of less than a few hundred meters (Hole $855 \mathrm{C}$ is located $125 \mathrm{~m}$ from the scarp) provides a constraint on the rate of flow of seawater into basement. Results of a simple model for cold water injection and lateral flow shown in Figure 7 suggest that the Darcian (fluid volumetric flow) velocity may be as high as $0.5 \mathrm{~m} / \mathrm{yr}$. With the dimensions of the aquifer used in this model, the influx of water would total $25 \mathrm{~m}^{3} / \mathrm{yr}$ per meterlength of fault. This rate of flow is too low by roughly a factor of 30 to supply the flux of water required for the alteration observed in hydrothermal basement at Site 857 (see estimate below), and it is far too low to supply water to a hydrothermal vent field of any significant flux. For example, if water along a 5-km length of fault were supplied to a vent 


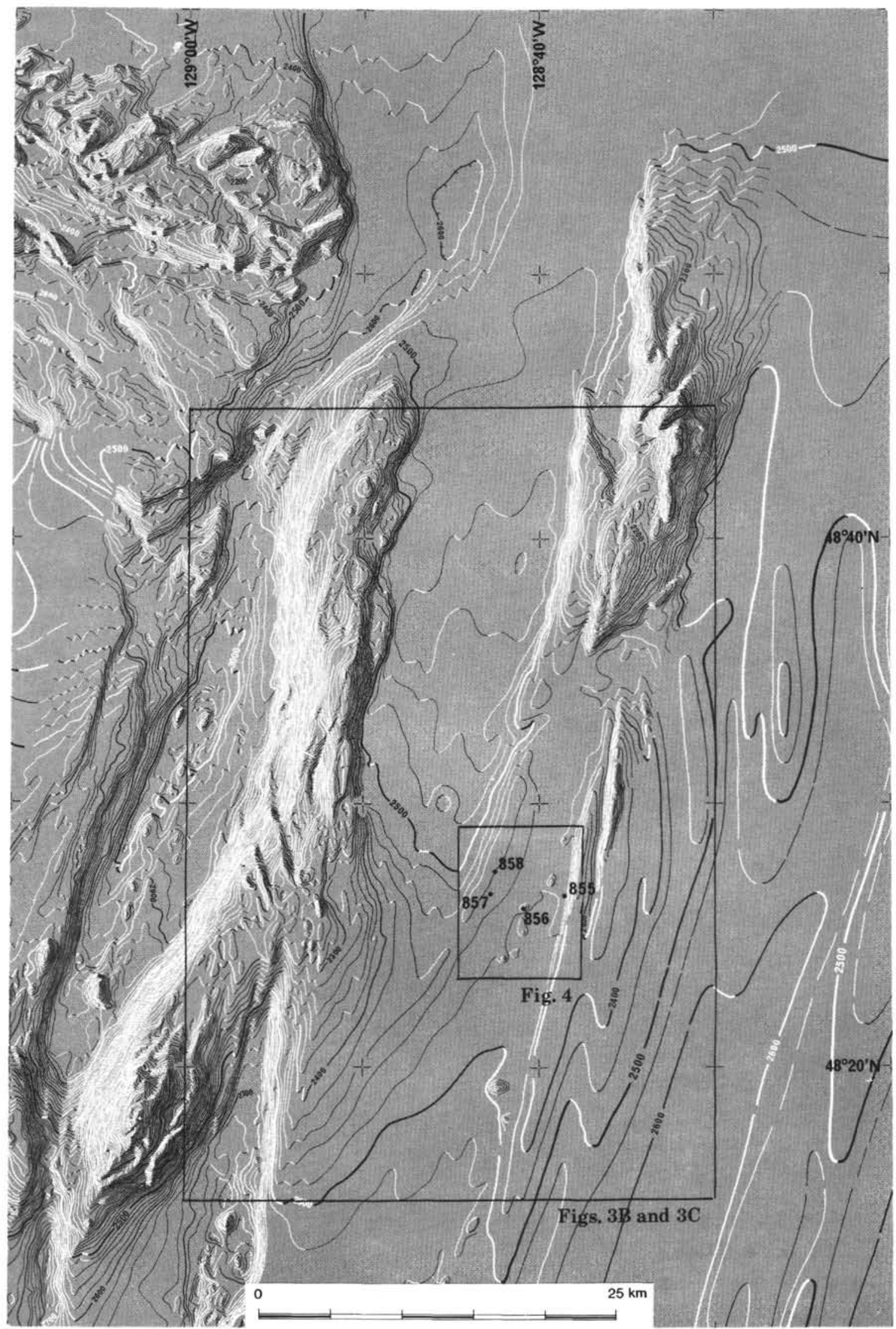

Figure 3. A. Bathymetry of Middle Valley, northern Juan de Fuca Ridge, shown as contours drawn at 20-m intervals and "illuminated" from the west. Site locations are shown, as are the areas included in Figures 3B and 3C (back-pocket foldout) and Figures 4A and 4B. 


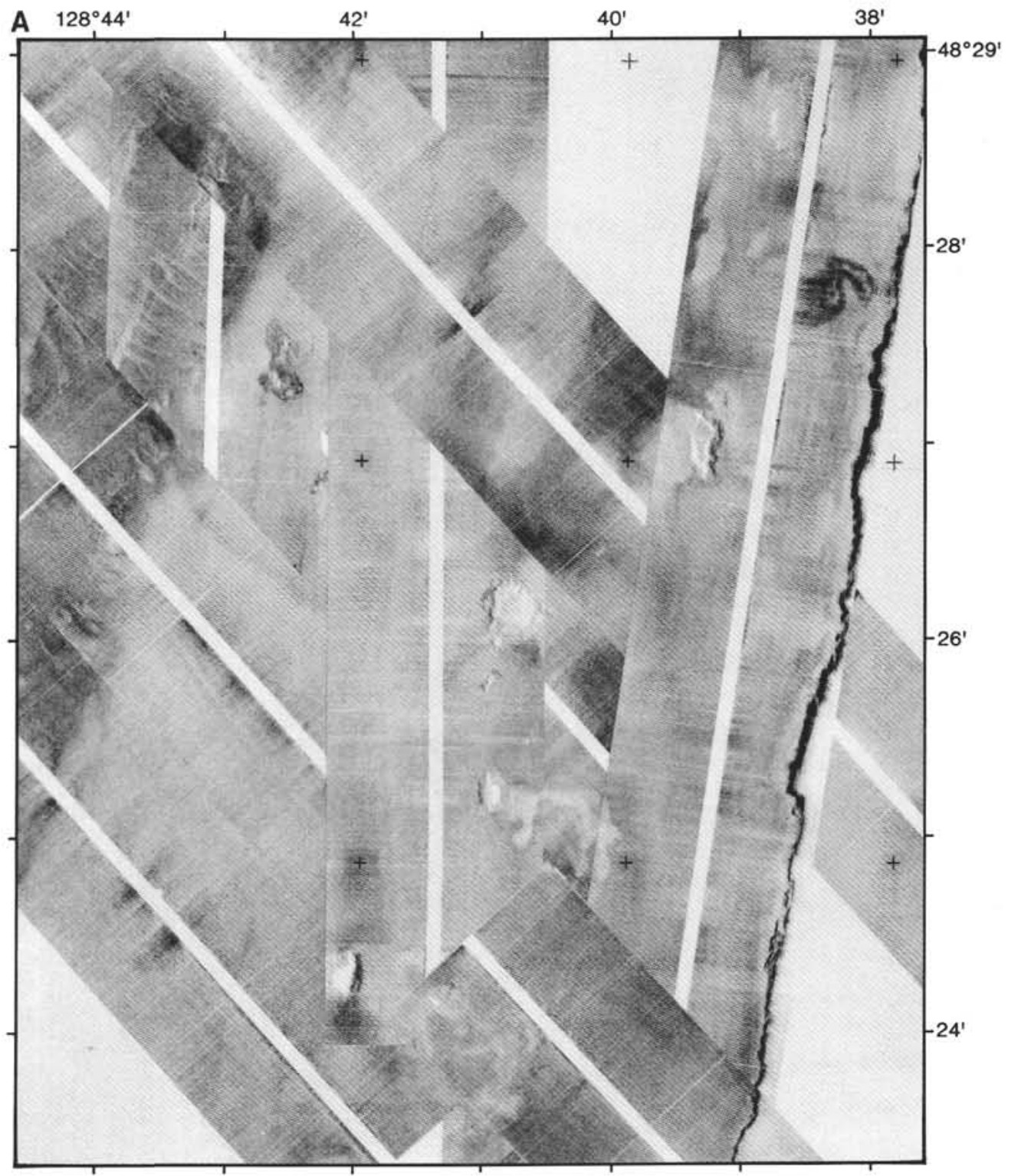

Figure 4. A. SeaMARC IA ( $30 \mathrm{kHz}$ ) acoustic image mosaic of the southeastern part of Middle Valley studied during Leg 139 (see Figures 3B and 3C for location). The image display polarity is the same as in Figure 3C (from H.P. Johnson, J.M. Franklin, and R.G. Currie, pers. comm., 1990). B. Interpretive map of area shown in Figure 4A, with drilling sites 855-858 (shown in detail in Figure 5) outlined.

field that discharged water at $400^{\circ} \mathrm{C}$, the heat dissipation would be only $0.6 \mathrm{MW}$. Thus most recharge to the hydrothermal circulation in Middle Valley must be derived elsewhere, probably via distributed slow flow through the sediment column.

\section{Site 857-Sealed Hydrothermal Basement}

Site 857 is located $5.2 \mathrm{~km}$ west of the Site 855 normal fault and about $1.5 \mathrm{~km}$ east of the major normal fault that forms the eastern boundary of the central part of the Middle Valley rift (Figs. 1, 4-6). Between the two faults, the crust is currently tilted down to the east as a single coherent block (Fig. 1; Davis and Villinger, 1992; Rohr and Schmidt, this volume). Site 857 is situated near the crest of this block, in an area where the heat flow is $700-800 \mathrm{~mW} / \mathrm{m}^{2}$. The primary objective at this site was to reach a permeable basement "reservoir," where hydrothermal circulation was inferred to occur beneath an integral sediment seal.

The section was sampled by four holes and comprises a 470-mthick sequence of turbidites overlying a sequence of basaltic sills interbedded with turbidites. Individual turbidite layers range from about 10 to $100 \mathrm{~cm}$ in thickness, with sharp, commonly scoured basal contacts, grading upward from massive, parallel-laminated, or convolute-bedded fine sand into turbiditic clay (Shipboard Scientific Party, 1992b; Rigsby et al., this volume). A distinct change was observed at $25 \mathrm{mbsf}$ (here as well as at nearby Site 858 ). Above this depth, intervals of mud commonly a few tens of centimeters thick are separated by layers of coarse turbiditic silt typically less than $1 \mathrm{~cm}$ thick (Lithologic Unit I). Below this depth (Lithologic Unit II), the thickness of the coarse turbiditic layers becomes distinctly greater, commonly more than $10 \mathrm{~cm}$. The change may be coincident with a change in sedimentation rate (just before $100 \mathrm{ka}$; see Fig. 8); both could be interpreted to mark the time of uplift of the fault block into which holes at this site and Site 858 were drilled.

Turbidite dilution and reworking, and hydrothermal alteration make absolute age constraints difficult to obtain at all Leg 139 sites. The best constraints are provided at Sites 856 and 857 by zonations of planktonic foraminiferal coiling directions (Brunner, this volume), and at Sites 855,856 , and 857 by the first appearance of the calcare- 


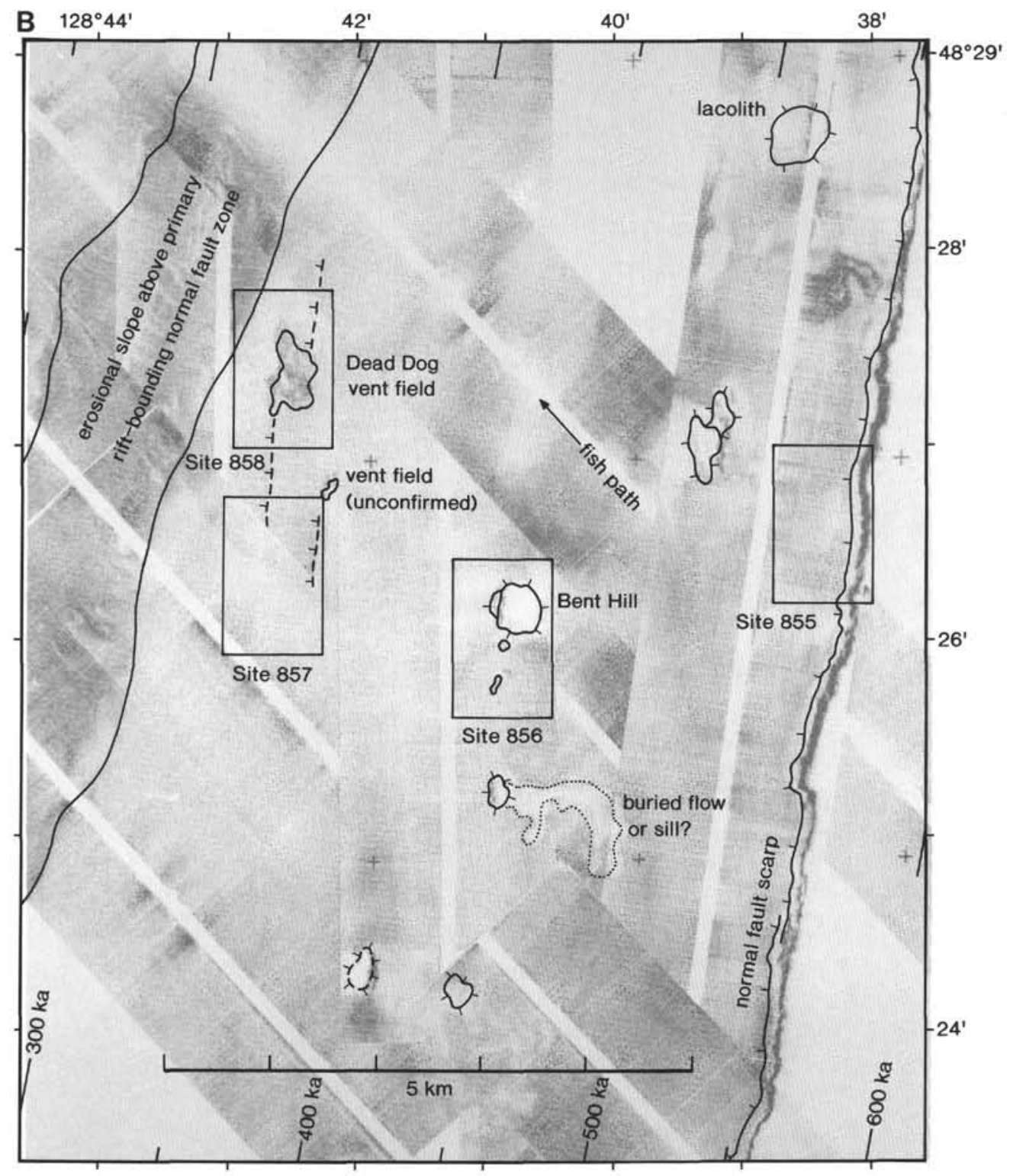

Figure 4 (continued).

ous nannofossil E. huxleyi (Mao and Wise, this volume). These data, together with the crude constraints placed on crustal age by the magnetic anomaly data (Currie and Davis, this volume; Fig. 4), and total sediment thickness by drilling and logging results (Langseth and Becker, this volume), are summarized for Site 857 in Figure 8. A simple history of average sedimentation (one that ignores the likely variations associated with waxing and waning glacial/interglacial sediment supply during the Pleistocene) is shown through the control points. Despite the uncertainties, it can be said with reasonable confidence that the sedimentation rate has greatly diminished through time. The inflection suggested above on the basis of the lithologic change at 25 mbsf is reasonable in light of the data. The minimum sedimentation rate required to accumulate the section below the 123 ka biostratigraphic datum is roughly $2.5 \mathrm{~mm} / \mathrm{yr}$, which is one order of magnitude greater than that defined for the upper part of the section.

Alteration generally increases with depth in the sediment section above the sill complex at this site. Clear indicators of alteration include a systematic decrease of magnetic susceptibility (Shipboard Scientific Party, 1992c); fossil dissolution, recrystallization, and maturation (Brunner, this volume; Mao and Wise, this volume; Mao et al., this volume); carbonate cementation (Baker et al., this volume; Buatier et al., this volume); silica diagenesis (Wheat and Tribble, this volume); and hydrocarbon maturation (Simoneit, this volume; Simoneit et al., this volume; Whelan et al., this volume). Changes in mineralogy and bulk geochemistry are generally minor, and most of the alteration can be accounted for by the high thermal gradient at this site. No major fluid flow is required.

Some fluid flow is suggested by the presence of locally anomalous pore fluid compositions in the interval spanning from roughly 200 to 400 mbsf (Shipboard Scientific Party, 1992c). Pore fluids in this interval compositionally resemble water venting at Site 858 , roughly $1.6 \mathrm{~km}$ to the north. Davis and Becker (this volume) infer from downhole hydrologic observations that a lateral gradient in effective pressure exists between the two sites, and that fluid may be driven laterally through the layered, anisotropically permeable sediments that bury a basement edifice at Site 858 . This possibility is discussed at greater length below.

Basement at Site 857 is unusual, but may be characteristic of the upper oceanic crust produced at sedimented seafloor spreading centers (e.g., Curray, Moore, et al., 1982; Tamaki, Pisciotto, Allan, et al., 1990; Fisher and Becker, in press). The first of a thick sequence of basaltic sills interbedded with turbidite sediments was intersected by 

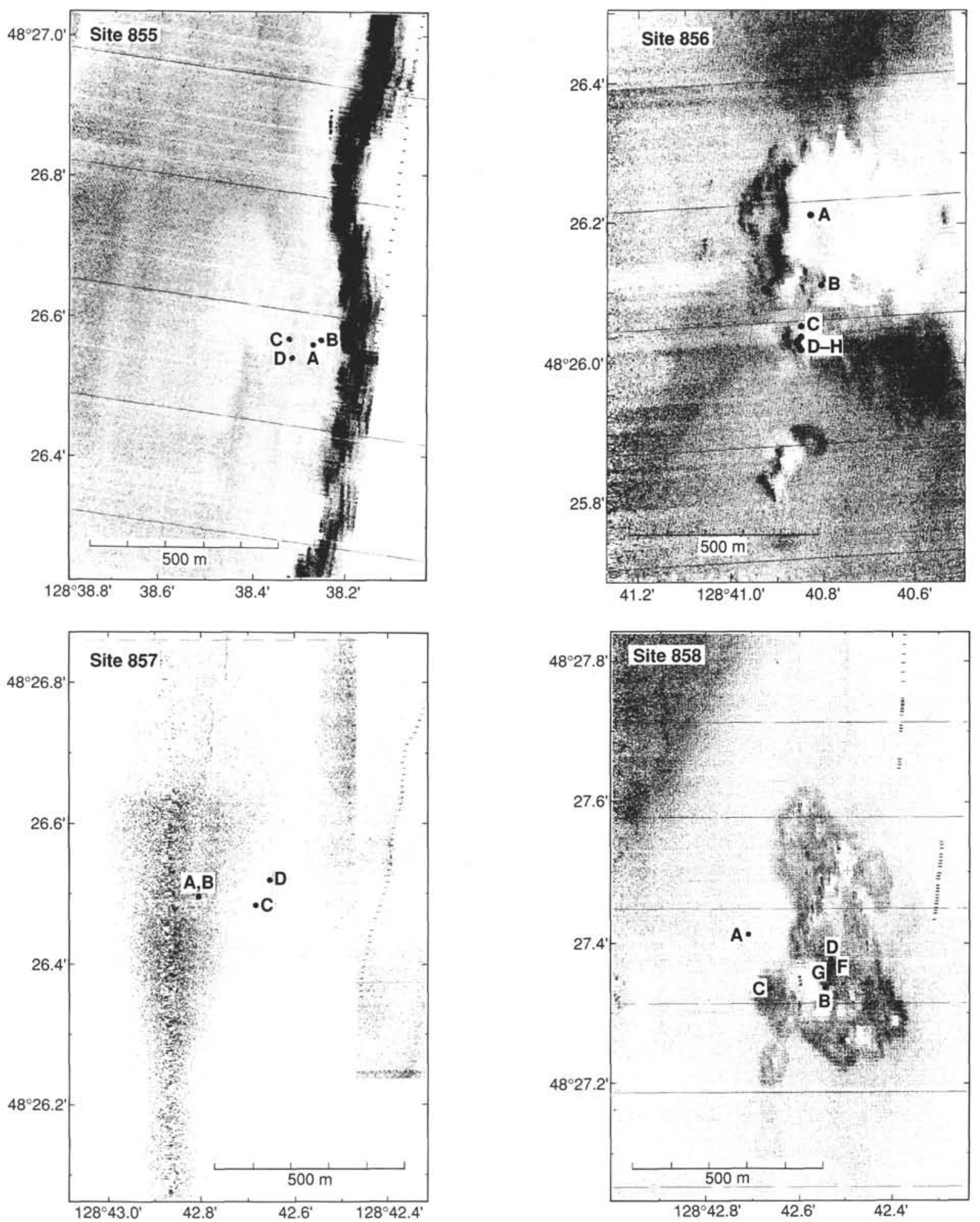

Figure 5. Hole locations at Leg 139 drilling sites superimposed on SeaMARC IA acoustic imagery (see Figure 4B for locations) (Shipboard Scientific Party, 1992a-d).

Holes $857 \mathrm{C}$ and $857 \mathrm{D}$ at depths of 471 and $463 \mathrm{mbsf}$, respectively. This sequence extended below this depth to the bottom of Hole 857D at 936 mbsf. Twenty-seven distinct sills were identified in total gamma and electrical resistivity logs, varying from 1 to $25 \mathrm{~m}$ in thickness. The cumulative thickness of the sills drilled makes up $40 \%$ of the total thickness of the sequence, and there is no change in the general ratio of igneous to sedimentary rocks throughout the drilled interval (Langseth and Becker, this volume). Based on the nature of local sediment deformation in the vicinity of the sills and on log correlations between parts of the sediment sections at Sites 857 and 858 (Shipboard Scientific Party, 1992c; Langseth and Becker, this volume), the sills appear to have been injected at a relatively early stage 

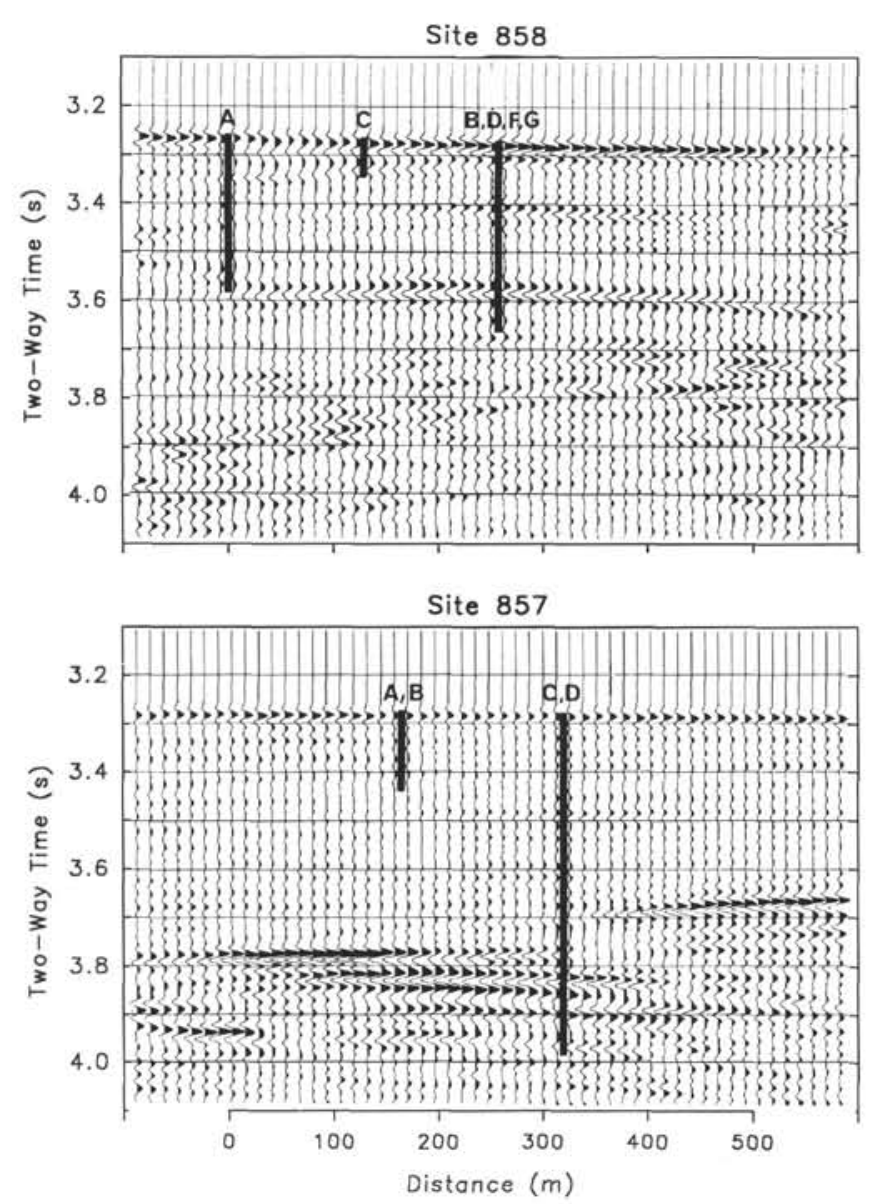
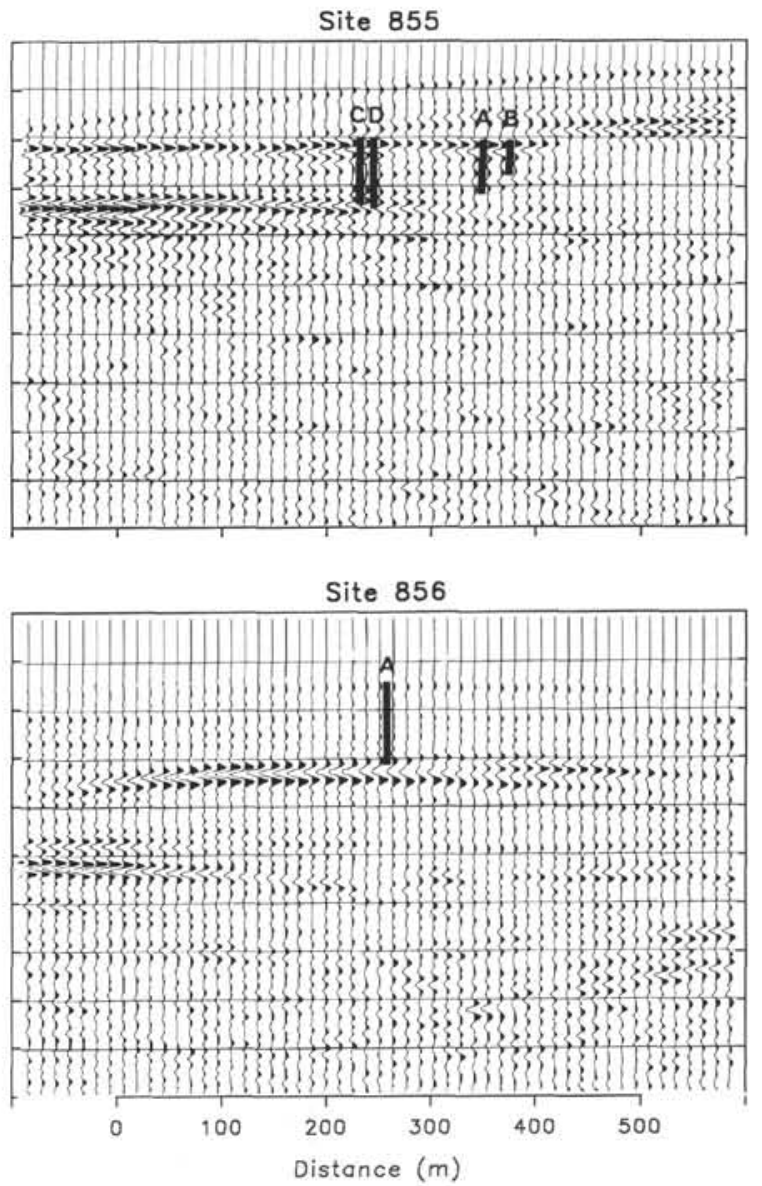

Figure 6. Near-trace seismic reflection sections of parts of lines shown in Figure 1. Drilling sites and approximate equivalent depths of penetrations are projected onto the profiles. The deepest hole is shown in cases of superimposed hole locations. All profiles are oriented with east to the right.

in the history of sedimentation, and at a fairly high level in the sediment section that existed at the time $(100-200 \mathrm{~m}$ below the paleo-seafloor).

The uppermost sills here and elsewhere in the valley are highly reflective, and can be identified by strong seismic reflections that typically are larger in amplitude than the seafloor reflection (Fig. 6; Rohr and Schmidt, this volume; Shipboard Scientific Party, 1992c). At most locations, sills are too closely spaced to be identified by discrete reflections, and the sequences produce reverberant wave trains (Rohr and Gröschel-Becker, this volume). Depths to the shallowest sill reflections vary only slightly parallel to structure in the vicinity of Site 857 , whereas across strike, depths vary substantially. On this basis, Rohr and Schmidt (this volume) identified three separate elongate sill units in the eastern part of the valley. Alternatively, the seismic structure could be interpreted with a history in which most of the uppermost reflectors are approximately coeval sills produced at the end of the same igneous episode, with most of the vertical displacement having been produced by normal faulting after their emplacement. Differences in the present depth to the uppermost sills may also reflect differences in the depths of emplacement that could have arisen from differences in hydrothermal alteration.

Although pure igneous basement was never reached by drilling at Site 857 , "hydrothermal basement," the drilling objective for this site, was encountered. Bulk permeabilities measured in the lowermost 180 $\mathrm{m}$ interval of Hole $857 \mathrm{D}$, and in the uncased portion of Hole $858 \mathrm{G}$, were on the order of $10^{-14} \mathrm{~m}^{2}$ (Fig. 8), similar to values obtained in the upper sections of basement in other holes drilled into young crust created at unsedimented spreading centers (Becker et al., this volume), and sufficiently high to support hydrothermal convection (Bessler et al., this volume). In contrast, permeabilities characteristic of the overlying sediment section were determined to be roughly two orders of magnitude less (Fig. 8; Fisher et al., this volume), sufficiently low to inhibit convection and to allow the sediment cover to serve as an effective hydrologic seal (Bessler et al., this volume).

Within the "basement" section, several zones of exceptional hydraulic conductivity were intersected. Two discrete zones supporting high rates of fluid flow were identified with a flowmeter log in Hole $857 \mathrm{D}$ at roughly 610 and $685 \mathrm{mbsf}$ (Becker et al., this volume) and a third was identified with a temperature log at about 840 mbsf (Langseth and Becker, this volume). The zones, inferred to be normal faults, were estimated to have apparent permeabilities on the order of $10^{-10}$ $\mathrm{m}^{-2}$ (Becker et al., this volume). The spatial frequency of these highpermeability zones, and the degree to which they may be interconnected, can only be surmised indirectly. Seismic profiles (Davis and Villinger, 1992; Rohr and Schmidt, this volume) show numerous normal faults at depth that are now inactive and buried by several hundred meters of sediment; these are spaced typically less than one to a few kilometers apart (e.g., Fig. 1). The large volumes of downhole-flowing seawater accepted by the fractures that were intersected in Hole 857D (Shipboard Scientific Party, 1992c; Becker et al., this volume) indicate either a large formation capacity within the fault zones themselves, or a high degree of fracture interconnection, sufficient to accept the 10,000 liters/min downhole flow observed. Results of hydrologic modelling (Bessler et al., this volume), together with estimates of the temperature and pressure variations in basement (Davis and Villinger, 1992; Davis and Becker, this volume) imply that fractures must play a significant role in controlling the effective bulk permeability of the crust. Model results suggest a bulk permeability for hydrothermal basement of 


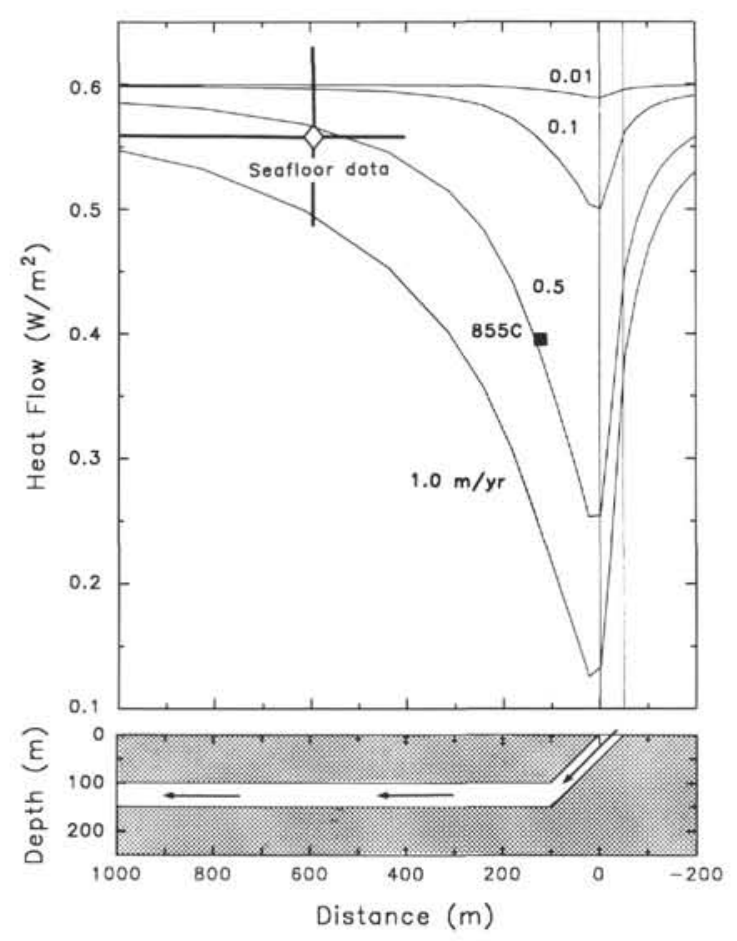

Figure 7. Seafloor heat-flow profiles predicted by a simple 2-D finite-element model simulating the effects of initially cold water flowing into a dipping fault zone and laterally along a horizontal aquifer, a situation inferred for Site 855 . A thermal conductivity of $1.5 \mathrm{~W} / \mathrm{m}-\mathrm{K}$, a porosity of $15 \%$, and a basal heat flow of $0.6 \mathrm{~W} / \mathrm{m}^{2}$ were used for the calculation. Results shown for several rates of flow are compared to the heat flow measured several hundred meters from the fault outcrop at Site 855 (Davis and Villinger, 1992), and to that determined in Hole $855 \mathrm{C}$

$>10^{-12} \mathrm{~m}^{2}$; this value is below the fault-zone values, but well above the values measured in intervals that do not include faults (see Fig. 8).

Geochemical evidence also supports the notion of hydrothermal basement and furthermore suggests a good connection between the fractures and the intervening regions of lower-permeability basement. Without exception, sediments within hydrothermal basement were found to be highly altered (Fig. 8; Shipboard Scientific Party, 1992c). The degree of alteration requires a large flux of fluid throughout the basement section (see discussion below).

The change in permeability between "hydrothermal basement" and the overlying sediment column was not observed directly, although it is inferred to occur relatively abruptly near the top of the sill sequence. This is suggested by several lines of evidence:

1. Subvertical fractures typically can be seen cutting the sills and adjacent sediments in formation microscanner (FMS) logs (Shipboard Scientific Party, 1992c; Langseth and Becker, this volume) and in cores. The fractures are wide (up to $1 \mathrm{~cm}$ ), and although mineralized, contain visible void space (Shipboard Scientific Party, 1992a).

2. Downward extrapolations of high-quality temperature data collected in the upper $80 \mathrm{~m}$ of the sediment section using thermal conductivity estimates corrected for the effects of temperature and anisotropy (Davis and Seemann, this volume; Villinger et al., this volume) yield a temperature of roughly $280^{\circ} \mathrm{C}$ at $470 \mathrm{mbsf}$ near the top of the sills (Fig. 8; Davis and Wang, this volume; Villinger et al., this volume). This temperature is virtually the same as that of seafloor vent fluids at Site $858,1.6 \mathrm{~km}$ away. The similarity in temperature implies the existence of a high-permeable pathway between this level in the section at Site 857 and the vents at Site 858 .
3. Sediments throughout the sill complex are highly altered as a result of fluid circulation at high water-rock ratio conditions (see discussion below). This character extends to just above the level of the uppermost sill (Fig. 8).

The igneous rocks at Site 857 are also pervasively hydrothermally altered, and as a result, possess low magnetization, on the order of 0.1 $\mathrm{A} / \mathrm{m}$, roughly two orders of magnitude less than normal for young, upper oceanic crust (Shipboard Scientific Party, 1992c; Fukuma et al., this volume). The extrusive rocks drilled at Site 858 also are observed to be weakly magnetized. On the basis of a major perturbation to the central magnetic anomaly observed over the valley, Currie and Davis (this volume) conclude that the igneous crust is weakly magnetized nearly throughout the current limits of the sediment-filled Middle Valley rift. This is probably the case wherever oceanic crust is produced under or is rapidly buried by a blanket of sediment (e.g., Curray et al., 1978; Larson, 1972).

\section{Site 858-Active Discharge}

Site 858 is centered over the large "Dead Dog" hydrothermal vent field, where fluids discharge through the sedimented seafloor at temperatures of up to $276^{\circ} \mathrm{C}$. Drilling objectives there included characterizing the nature of the upflow zone beneath the vent field, determining the cause of the focused discharge at this location, and sampling the products of, and alteration produced by, the fluid flow through the upper crust, sediment section, and seafloor.

Clues as to why the hydrothermal discharge is localized here were provided by site survey data (Davis and Villinger, 1992; Shipboard Scientific Party, 1992d). Seismic reflection data show the vent field to be situated directly above a local basement edifice, where the hydrologically resistive sediment cover is locally attenuated (Figs. 1 and 6); side-scan acoustic imagery shows the field to be located along a normal-fault trace with a small offset (Figs. 4 and 5). Both may contribute to providing permeable pathways between the regional hydrothermal basement reservoir sampled at Site 857 and the seafloor at Site 858 .

Drilling at Site 858 confirmed that the vent field is underlain by a local basement edifice. Holes $858 \mathrm{~F}$ and $858 \mathrm{G}$ entered extrusive igneous rock at $258 \mathrm{mbsf}$; penetration of extrusive rocks continued in Hole $858 \mathrm{G}$ to the total drilled depth of $433 \mathrm{mbsf}$. Recovery was poor (about $5 \%$ ), but logging results demonstrated clearly that there are no significant accumulations of sediment in the entire igneous section (Shipboard Scientific Party, 1992d). Langseth and Becker (this volume) speculate that this center of volcanism may have been the source of the intrusive sills seen elsewhere in this part of the valley. Compositions of the igneous rocks at Sites 857 and 858 are similar and do not preclude this possibility (Shipboard Scientific Party, 1992d; Stakes and Franklin, this volume).

Although no zones of extreme hydraulic conductivity like those at Site 857 were encountered, the basement section penetrated at Site 858 is sufficiently permeable to support hydrothermal circulation. Values determined in the open Hole $858 \mathrm{G}$ below casing average about $2 \times 10^{-14} \mathrm{~m}^{2}$ (Becker et al., this volume), further supporting the concept of a permeable hydrothermal basement and a potential efficient interconnection at depth between Sites 857 and 858 .

Permeable pathways, either channelized or diffuse, must also be present in the sediment section directly beneath the vent field at Site 858 to allow the ascent of basement fluids that feed the seafloor vents and to maintain the high temperatures observed at shallow levels. Fractures were identified in FMS logs commonly in the deeper part of the sediment section (Shipboard Scientific Party, 1992d; Langseth and Becker, this volume). Thermal perturbations associated with the flow of cold seawater down the exploratory Hole $858 \mathrm{~F}$ were observed in that hole and throughout the adjacent cased and sealed Hole 858G (Shipboard Scientific Party, 1992d; Davis and Becker, this volume), indicating high lateral permeability. These observations, along with 

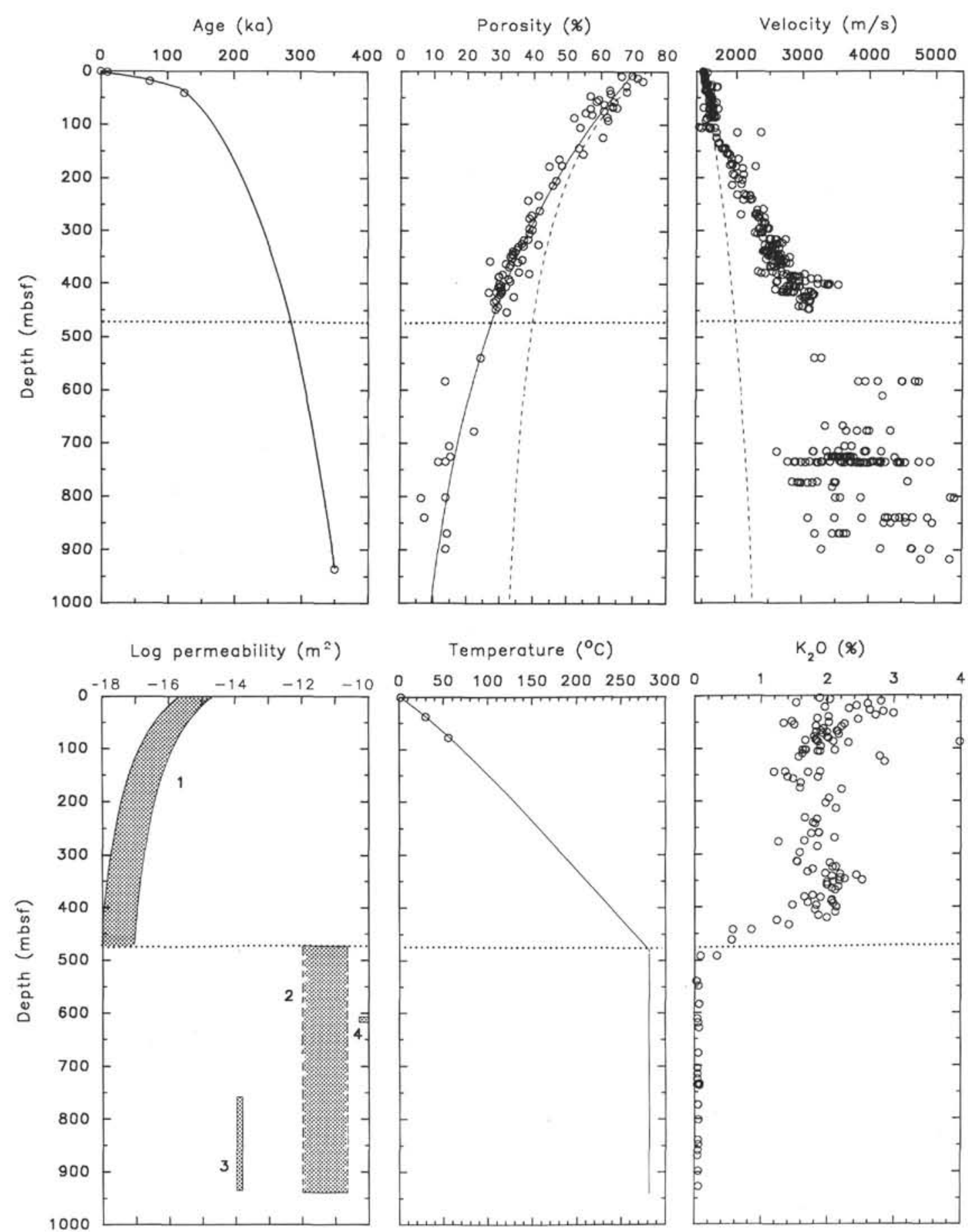

Figure 8. Summary of shipboard, downhole, and shorebased data that characterize the sediments at Site 857. The depth of the top of the first sill is shown as the horizontal dotted line. Age constraints are provided by biostratigraphic data (Brunner, this volume; Mao and Wise, this volume), and by the position of the site within the Brunhes Magnetic Chron (Currie and Davis, this volume). Sediment porosities and velocities (Shipboard Scientific Party, 1992c) are compared to the unaltered "reference curves" (dashed lines) described in the text. Permeability of the section above the top of the first sill (1) is derived from the porosity-depth curve (solid line) fitted through the porosity data, and relationships that bracket the majority of the consolidation data of Fisher et al. (this volume). Permeabilities shown for the deeper part of the section ("hydrothermal basement") are estimates (2) from the model results of Bessler et al. (this volume), and values from downhole packer measurements ( 3 and 4 ) of Becker et al. (this volume). The temperature profile is estimated from APC temperature probe data and conductivity profiles estimated by Villinger et al. (this volume) and Davis and Wang (this volume). The permeable part of the section below 470 mbsf is shown as isothermal; this is supported by fluid inclusion temperatures (Peter et al., this volume) but has not been ascertained. Potassium contents are from Goodfellow and Peter (this volume). 
the observation that the sediment section is highly altered below about 30 mbsf (see discussion below), strongly suggest that a significant component of permeability, and thus upflow, is distributed in fairly closely spaced channels.

This is not the case for the uppermost $25-30 \mathrm{~m}$ of the section, where the sediments were penetrated with the hydraulic piston corer (APC) and were physically remarkably "normal" (Shipboard Scientific Party, 1992d). APC penetration extended to $32.5 \mathrm{~m}$ in Hole $858 \mathrm{~B}$ and $28.8 \mathrm{~m}$ in Hole $858 \mathrm{D}$. Except at the vents themselves, heat flow is dominantly conductive in this depth interval, and although the thermal gradient was high (a temperature of $196^{\circ} \mathrm{C}$ was measured at $19 \mathrm{mbsf}$ in Hole $858 \mathrm{~B}$, and $208^{\circ} \mathrm{C}$ at $21 \mathrm{mbsf}$ in $858 \mathrm{D}$ ), the physical properties and chemical characteristics of the sediment indicate only mild alteration (see discussion below). This was true even in the case of Hole $858 \mathrm{~B}$, which was drilled about $10 \mathrm{~m}$ from an active vent. Fluid flow through this part of the section that feeds the vents therefore must be highly focused. Pore-fluid geochemical anomalies are present in the uppermost part of the sediment section, but these are highly localized and indicate primarily lateral transient flow (Shipboard Scientific Party, 1992d).

The transition between the uppermost, physically "normal" part of the section and the deeper, highly altered sediments is extremely abrupt. This was demonstrated by a sharp decrease in the rate of drilling penetration (ROP) and the sudden failure of APC penetration. The sharp transition lies at a depth close to one-half seismic wavelength (at $30 \mathrm{~Hz}$ ) below the seafloor; this provides a simple explanation for the strong seismic reflection observed locally over the vent field (Fig. 6; Rohr and Gröschel-Becker, this volume). Unfortunately, core recovery dropped dramatically at the transition (from close to $100 \%$ in the uppermost $30 \mathrm{~m}$ to an average of about $3 \%$ in the section below), and the true nature of the deeper part of the section could not be described with confidence. Bulk compositions and physical properties of the recovered material indicated extreme induration of the sediments (see discussion below), although local contrasts associated with the original turbidite lithology are remarkably well preserved (Shipboard Scientific Party, 1992d).

A portion of the section from 100 to 210 mbsf in Hole $858 \mathrm{~F}$ can be correlated with a portion of the section from 150 to 280 mbsf in Hole $857 \mathrm{C}$, using electrical resistivity logs that are sensitive to porosity and clay content (Shipboard Scientific Party, 1992d; Langseth and Becker, this volume). On the basis of this correlation, and the contrast in the lithologies below the depth of the correlative turbidite sequences (with the deep part of the section at Site 858 being considerably finer grained, dominantly claystone), Langseth and Becker (this volume) develop a relatively simple history for the two sites. This involves (1) roughly coeval development of the extrusive volcanic edifice at Site 858 and the sill complex at Site 857 , early in the history of sedimentation; (2) continuing rapid turbidite deposition at Site 857 and slow hemipelagic blanketing of the high-standing edifice at Site 858 ; and (3) eventual turbidite deposition (of the correlative parts of the sections) at both sites, as the base level of sedimentation reached the summit of the edifice. Differences in thicknesses and absolute depths of the correlative parts of the sections are probably due to differential tectonic subsidence across the tilted fault block in which the holes are located, and differences in consolidation of the thick sediment section at Site 857 and the thin sediment section at Site 858: There is only $50 \mathrm{~m}$ of sediment beneath the correlative section at Site 858 , whereas there is at least $480 \mathrm{~m}$ beneath the correlative section at Site 857 ( $190 \mathrm{~m}$ above the top of the sill sequence).

The history of hydrothermal discharge through sediment burial of the edifice at Site 858 is not well constrained, although the following shipboard observations suggest that the history has been relatively simple:

1. The present-day temperatures of most vents in the field range from $255^{\circ} \mathrm{C}$ to $265^{\circ} \mathrm{C}$, up to a maximum of $276^{\circ} \mathrm{C}$.
2. Only minor accumulations of sulfide minerals or other hightemperature $\left(>350^{\circ} \mathrm{C}\right)$ hydrothermal products have been observed in outcrop at the seafloor in the Site 858 vent field (Shipboard Scientific Party, 1992d).

3. Only minor sulfide mineralization was encountered by drilling.

4. Alteration of the basement rocks at Site 858 is extensive but does not indicate that large volumes of high-temperature $\left(>350^{\circ} \mathrm{C}\right)$ fluids have circulated through the section. Metamorphic mineral assemblages are characteristic of upper zeolite to greenschist grade, with estimated alteration temperatures ranging up to $300^{\circ} \mathrm{C}$. Thus the simplest history at the site is one in which discharge has occurred at a relatively constant temperature throughout the history of hydrothermal activity.

Upflow at Site 858 appears to have been confined primarily to a zone directly beneath the present-day vent field throughout the history of discharge, which may have been as long as the total period of sedimentation over the basement edifice. Current focusing of fluid flow is indicated by the spatially abrupt boundary between the morphologically rough seafloor in the vent field (created by constructional vent edifices and debris mounds, and by unusually heavy bioturbation) and the smooth seafloor beyond (Shipboard Scientific Party, 1992d; Figs. 4 and 5). It is also seen more quantitatively in the high lateral gradients in heat flow surrounding the field (Davis and Villinger, 1992; Shipboard Scientific Party, 1992d). Temperatures measured in Holes 858A and $858 \mathrm{C}$, drilled adjacent to the vent field, can be accounted for by a simple conductive model that includes a vertically bounded hot upflow zone (Fig. 9). That the upflow has been confined primarily to the zone directly above the basement edifice intersected by Holes $858 \mathrm{~F}$ and $858 \mathrm{G}$ is suggested by the strong lateral gradient in alteration defined by samples from all Site 858 holes (Shipboard Scientific Party, 1992d; see discussion below). Hole $858 \mathrm{~A}$, located only $100 \mathrm{~m}$ west of the area of the vent field (as defined by the high level of acoustic backscatter in side-scan images), was drilled to a total depth of $339 \mathrm{mbsf}$. No igneous rocks were encountered, and only moderate alteration is present in the sediment section. This contrasts with the high level of alteration observed below 30 mbsf beneath the vent field itself, presumably the result of long-lived fluid flow.

Permeability within the zone of focused upflow is probably promoted by the mechanical competency of the hydrothermally altered sediment and maintained by tectonic displacements (Figs. 4 and 5) and hydraulic fracturing (Davis and Becker, this volume; Shipboard Scientific Party, 1992d; see discussion below), despite vein filling and porosity loss through mineralization. The cause of the sharp transition from relatively unaltered to highly altered sediment at $30 \mathrm{mbsf}$ is not yet understood.

An estimate for the current rate of fluid flow beneath the vent field at Site 858 can be obtained by assuming that the elevated average heat flow observed in the Dead Dog vent field of roughly $12 \mathrm{~W} / \mathrm{m}^{2}$, or the concave-down temperature profile suggested by the temperature data from Holes $858 \mathrm{~F}$ and $858 \mathrm{G}$, is due simply to vertical flow of $280^{\circ} \mathrm{C}$ pore fluid (Davis and Villinger, 1992; Langseth and Becker, this volume). Darcy velocities of roughly $0.5 \mathrm{~m} / \mathrm{yr}$ are required. Alternatively, there could be an abrupt transition between a primarily conductive thermal regime in the uppermost $30 \mathrm{~m}$ of the sediment column, with advective flow limited to discrete vents, and a convective regime in more permeable sediments below. In this case, higher rates of flow would be required to maintain a thin boundary layer beneath a lowpermeability "cap" and roughly isothermal conditions within the high-permeability upflow zone.

A simple model that accounts for the pressure gradient that serves to drive fluid flow through the sediment column has been proposed by Davis and Becker (this volume) on the basis of long-term CORK (Circulation Obviation Retrofit Kit) pressure observations in sealed Holes $857 \mathrm{D}$ and $858 \mathrm{G}$. They estimate that formation fluid pressure in the permeable sill complex penetrated by Hole $857 \mathrm{D}$ is close to hydro- 

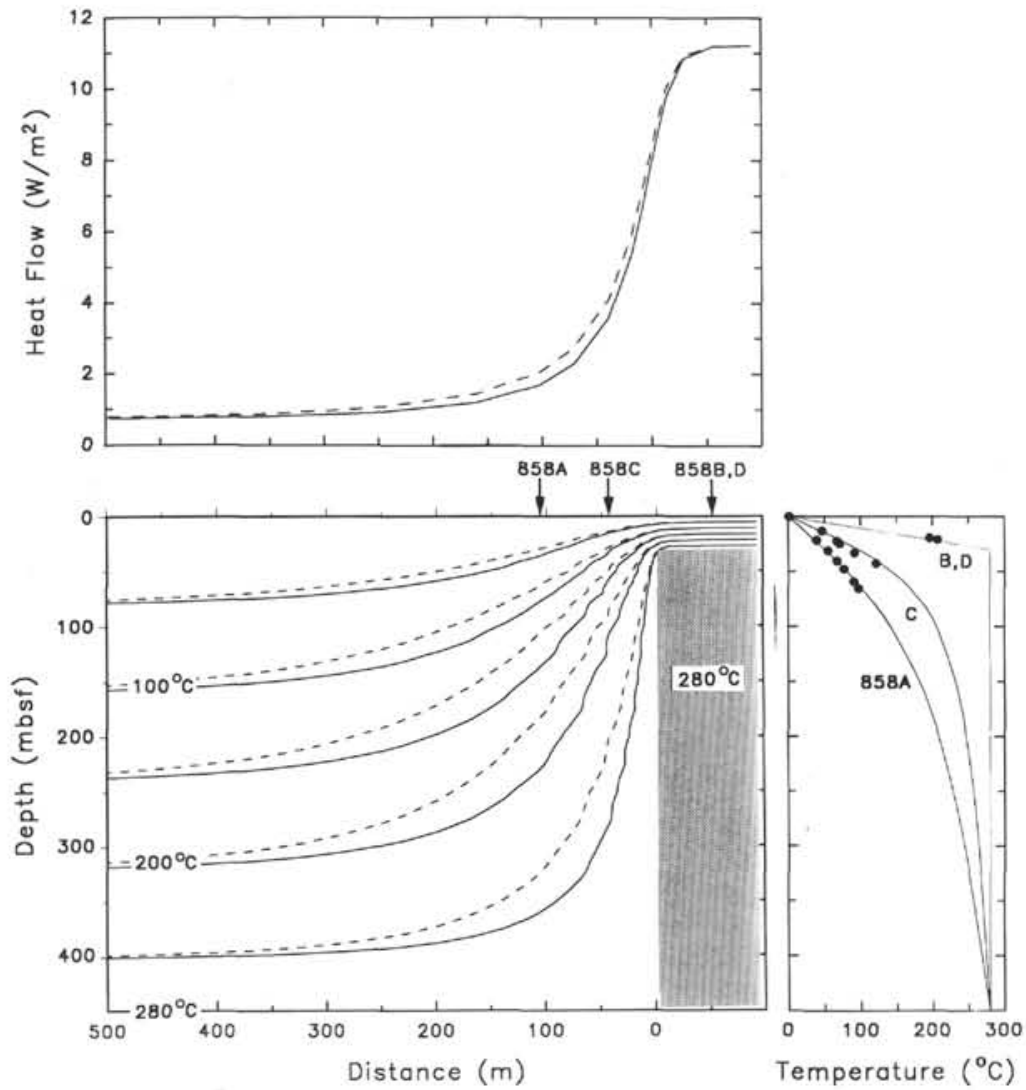

Figure 9. Sea-floor heat flow, isotherms, and temperature profiles predicted by 2-D (hot prism; dashed lines) and 3-D (axisymmetric chimney; solid lines) finite element models simulating the thermal regime at Site 858. Purely conductive heat transfer is assumed outside the isothermal core. Temperature measurements in Holes $858 \mathrm{~A}$ and $858 \mathrm{C}$ compare remarkably well with the model results, despite the simplifying assumptions. On the basis of this agreement, it can be inferred that advective heat transport is not significant outside the isothermal upflow zone. static (as defined by the local geotherm), whereas fluids in the top of the permeable basement edifice intersected by Hole $858 \mathrm{G}$ may be overpressured relative to the local geothermal hydrostat by as much as $450 \mathrm{kPa}$. Davis and Becker (this volume) suggest that this is a simple consequence of pressures in the permeable hydrothermal basement being set regionally by the most representative (conductive) conditions. Pressures in the permeable volcanic edifice at Site 858 are tied to this "reference" rather than to the sea floor immediately overhead. Because of the large density contrast between the $280^{\circ} \mathrm{C}$ hydrothermal water and the cooler water that hydrostatically "loads" basement regionally, pressure differentials can be generated that are much larger than the differentials associated with convective instabilities within basement (probably $<100 \mathrm{kPa}$; Bessler et al., this volume).

A crude estimate of the bulk permeability of the sediment in the upflow zone at Site 858 can be derived from this "choked-chimney" model using the following assumptions and constraints: (1) the maximum estimated pressure differential of $450 \mathrm{kPa}$ is lost in the upflow zone uniformly over the entire $260 \mathrm{~m}$-thick sediment column; and (2) the upflow velocity is $0.5 \mathrm{~m} / \mathrm{yr}$ (the minimum vertical fluid flow required to maintain the observed thermal boundary layer as estimated above). Using Darcy's law and a viscosity of $10^{-4} \mathrm{~Pa}$-s yields an effective bulk permeability of $10^{-15} \mathrm{~m}^{2}$. This number is intermediate to the values estimated for basement away from fault zones (roughly $10^{-14} \mathrm{~m}^{2}$; Becker et al., this volume) and those typical for sediments where alteration is minor (typically $10^{-16} \mathrm{~m}^{2}$; Fisher et al., this volume).

A probable departure from this uniform case is one in which a greater proportion of the pressure drop occurs in the uppermost $30 \mathrm{~m}$ of the section. In that interval, the physically unaltered sediments are not sufficiently competent to support open fractures (except directly beneath vents), and the sediment permeabilities measured by Fisher et al. (this volume) probably are generally representative. Furthermore, fluid viscosity increases by an order of magnitude in the upper conductive boundary layer, leading to much greater hydraulic resistance there.
In the extreme case in which most of the pressure is lost in the uppermost part of the sediment section, lithostatic pressures could develop, leading to hydrofracturing (Davis and Becker, this volume). That this situation may occasionally occur is suggested by the presence of brecciated sediment above about 50 mbsf in several of the holes drilled in the vent field (Shipboard Scientific Party, 1992d).

One other consequence of the choked-chimney effect is that fluids may be forced laterally from the summit of the permeable basement edifice, or wherever overpressures may occasionally develop, and into the surrounding sediment section where effective pressures are lower. Lateral fluid flow was in fact suggested as an explanation for the locally anomalous composition of pore fluids at depths from about 200 to $400 \mathrm{mbsf}$ in Hole $857 \mathrm{C}$, where pore fluids are chemically similar to the vent fluids at Site $858,1.6 \mathrm{~km}$ distant (Shipboard Scientific Party, 1992c; Butterfield et al., this volume). The anomaly spans the depth of the basement edifice at Site 858. Lateral flow from the upflow zone is also suggested by the presence of local pore-fluid geochemical anomalies and strata-bound mineralization in Holes 858 A and 858C (Shipboard Scientific Party, 1992d).

In addition to being driven by lateral pressure differentials, lateral flow is undoubtedly assisted by the anisotropic permeability structure of the turbidite sediments. The degree of anisotropy can be estimated with a simple model for layered sediment in which the average permeability in the horizontal direction is determined by the arithmetic mean of the permeabilities of the constituent layers and the average in the vertical direction by the harmonic mean. Because of the large contrast in permeability between silty or sandy and clay-rich sediments, and the way in which such constituents combine to give the vertical and horizontal component averages, the degree of anisotropy as well as the individual component averages are relatively insensitive to the details of the lithology. This is illustrated in Figure 10, where the vertical and horizontal components of permeability are shown as functions of the percentage of the section occupied by sand layers. The mean permeability values in the horizontal and vertical 


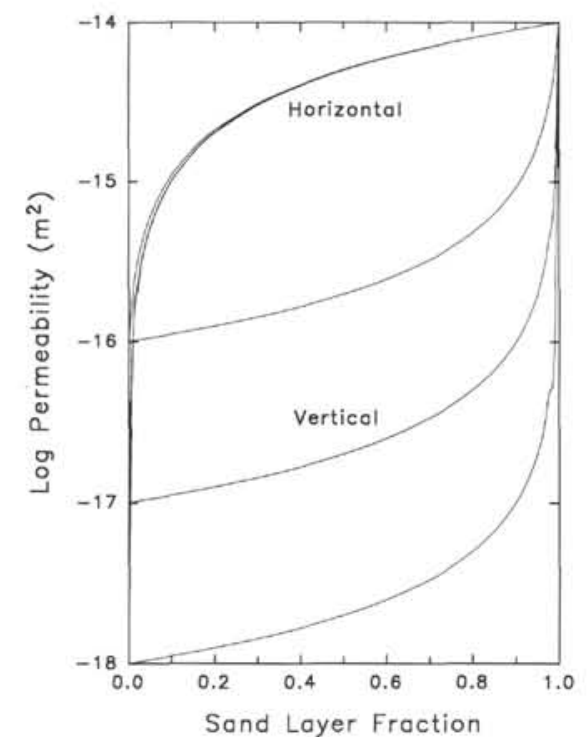

Figure 10. Horizontal and vertical components of permeability of a horizontally layered composite of sand and mud, plotted as functions of the proportion of sand layers in the total section. A value of $10^{-14} \mathrm{~m}^{2}$ has been used for the permeability of the sand layers, and three values, $10^{-16}, 10^{-17}$, and $10^{-18} \mathrm{~m}^{2}$, for the permeability of the mud.

directions are very close to the higher and lower constituent values, respectively, over a large range of sand-layer content, from about $10 \%$ to $90 \%$. Clearly, this effect must be considered in any hydrologic model for sediment-hosted hydrothermal upflow zones.

\section{Site 856—Relic Discharge and Massive Sulfides}

Site 856 is situated over "Bent Hill," one of a number of small hills in eastern Middle Valley, roughly midway between the eastern boundary fault along which Site 855 was located, and Sites 857 and 858 (Figs. 1, 3-6). All of the hills are underlain by bright seismic reflectors; drilling at Holes $856 \mathrm{~A}$ and $856 \mathrm{~B}$ confirmed that the reflector at this site is associated with a basaltic intrusion (Shipboard Scientific Party, 1992b). The intrusions are probably laccolithic in form and are inferred to be responsible for the uplift of the hills. Similar structures are common at other sedimented rifts, such as in Escanaba Trough (Davis and Becker, in press; Denlinger and Holmes, in press), and some have apparently associated hydrothermal sulfide deposits (e.g., Zierenberg et al., in press). In the case of Bent Hill, sulfides have been found in outcrop on the southern flank of the hill (Davis et al., 1987; Shipboard Scientific Party, 1992b; Tivey, this volume; Goodfellow and Franklin, in press), although the deposit appears to be relict. A local heat-flow anomaly has been defined by seafloor measurements (heat flow at Bent Hill exceeds $1 \mathrm{~W} / \mathrm{m}^{2}$ ), although the peak of the anomaly is centered neither over Bent Hill nor over the Bent Hill deposit, but rather over a currently active vent located $300 \mathrm{~m}$ south of the Bent Hill deposit. There, clear water currently vents at a temperature of $265^{\circ} \mathrm{C}$ (Davis and Villinger, 1992; Goodfellow and Franklin, in press; Shipboard Scientific Party, 1992b). No discharge has been observed at the Bent Hill deposit itself.

The primary goals of drilling at Site 856 were (1) to study the nature of the massive sulfide deposit and (2) to determine the relationships among volcanism, sediment deformation, and genesis of the sulfide body. Leg 139 was to a large degree successful in accomplishing the former objective, but elucidation of the latter remains incomplete. Holes $856 \mathrm{C}$ through $\mathrm{H}$ form a transect that crosses the highest, and presumably the central point, of a large constructional sulfide edifice just south of the perimeter of the uplifted hill (Fig. 5). A lower limit on the lateral extent of the sulfide body $(>60 \mathrm{~m})$ is provided by the transect; all holes penetrated either weathered, clastic, or massive sulfide. Likewise, a lower limit on the thickness of the deposit was determined by Holes $856 \mathrm{G}$ and $858 \mathrm{H}$, which both terminated in massive sulfide at depths of 65 and $94 \mathrm{mbsf}$, respectively. Only minor amounts of terrigenous or pelagic sediment were recovered by coring or were detected by logging. The mineralogy and textures of the primary sulfides and quartz-hosted fluid inclusions (Goodfellow and Peter, this volume; Peter et al., this volume) strongly suggest that the deposit at Site 856 formed by precipitation from high-temperature $\left(>350^{\circ} \mathrm{C}\right.$ to over $400^{\circ} \mathrm{C}$ ) hydrothermal fluids at or near the seafloor. Relatively low concentrations of $\mathrm{Pb}, \mathrm{Sb}$, and $\mathrm{As}$ in primary minerals suggest that the fluids from which the sulfides precipitated had not reacted with the sediment section at high temperatures (Shipboard Scientific Party, 1992b; Duckworth et al., this volume; Goodfellow and Peter, this volume; Krasnov et al., this volume). The relatively heavy sulfur isotopic composition of the sulfide minerals (about 6\%; Zierenberg, this volume) indicates a mixed source of sulfur, including basalt in the primary reaction zone, and reduced seawater, possibly from the regional, cooler hydrothermal basement. Mineral and elemental zonation, and fluid inclusion studies, indicate a significant degree of alteration of the deposit by circulation of cooler fluids during a waning phase of hydrothermal discharge.

While the proximity of the sulfide deposit to the uplifted hill suggests a genetic link, drilling results demonstrate that deposition of the sulfide body and intrusion of the laccolith beneath Bent Hill were separated considerably in time, and therefore that the features observed are probably not directly related (Shipboard Scientific Party, 1992b). Based on stratigraphic relationships, Mottl et al. (this volume) infer that the massive sulfide body was deposited during the Pleistocene and was already substantial by $140-220 \mathrm{ka}$, whereas the high-level laccolithic intrusion and the associated uplift of Bent Hill occurred during the Holocene, possibly within the past few thousand years. Alteration of the sediments in Holes 856A and 856B increases systematically both with depth and with proximity to the sulfide deposit and is clearly related to the hydrothermal discharge that formed the deposit, not to the intrusion of the laccolith (Shipboard Scientific Party, 1992b; Goodfellow and Peter, this volume).

\section{CONSEQUENCES OF FLUID FLOW Changes in Physical Properties of Sediments}

\section{Measurements}

In the discussion that follows, shipboard porosities and velocities are used in a hole-to-hole comparison in order to investigate the effects of hydrothermal sediment alteration. No attempt has been made to correct the measurements made at atmospheric conditions for the effects of hydrostatic pressure, overburden loading, or temperature. Because of this, and because of probable biases inherent in core recovery and shipboard sampling, the measurements probably are not representative of in-situ properties, and therefore should be treated with considerable caution. However, because hole-to-hole variations are large and systematic errors are similar in all holes, conclusions reached on the basis of comparisons of the data are not likely to be affected.

\section{Reference Section}

The only sediments drilled during Leg 139 that are unlikely to have been altered by the effects of high temperatures or hydrothermal fluid flow and that thus might serve as a background "reference" section are those at Site 855. Unfortunately, drilling at this site penetrated only 100 $\mathrm{m}$ of sediment, and the samples obtained with the rotary core barrel were highly disturbed. For estimating the relative effects of alteration at greater depths in the Middle Valley holes, we use results from Site 888, drilled in the Cascadia Basin off Vancouver Island during Leg 146 (Shipboard Scientific Party, in press) and studied seismically by Yuan et al. (1994). The lithologies there may differ from those in Middle Valley given the proximity of Site 888 to the Nitinat fan; the Cascadia 


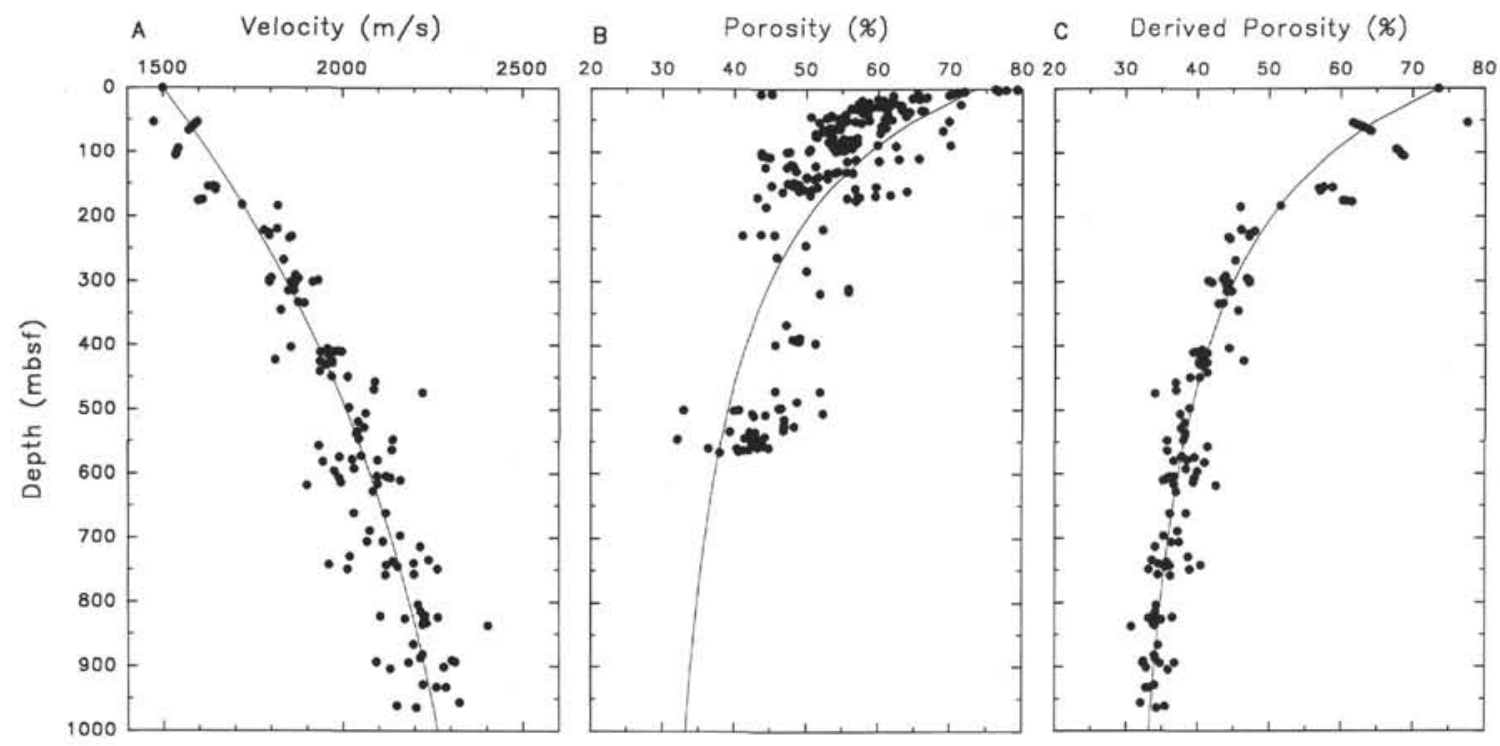

Figure 11. Physical properties of sediments of Cascadia Basin. A. Velocities determined from multichannel seismic normal-moveout analyses (Yuan et al., 1994), with the polynomial regression line fitted through the data as described in the text. B. Porosities measured on sediment samples from Hole 888 (Shipboard Scientific Party, in press). The smooth curve is from (C). C. Porosities derived from velocities and the velocity profile shown in (A), using the relationship given in Davis and Villinger (1992) that is based on data from Jarrard et al. (1989) and Han et al. (1986).

Basin sediments are likely to be coarser and have higher velocities and lower porosities than Middle Valley sediments at any given depth. Nevertheless, Site 888 is believed to be the most useful site for the comparisons discussed below. The data shown in Figure 11 include interval velocities obtained from several multichannel seismic profiles crossing and near Site 888 , through which a smooth curve has been fitted (from the seafloor to $1200 \mathrm{mbsf}$ ). The curve is defined by the polynomial

$$
\mathrm{V}=1500+1.346 \cdot \mathrm{z}-7.43 \times 10^{-4} \cdot \mathrm{z}^{2}+1.62 \times 10^{-7} \cdot \mathrm{z}^{3},
$$

and is used for reference in the discussion that follows.

Also shown in Figure 11 are shipboard porosity data for sediment from Site 888 (Shipboard Scientific Party, in press) and porosities predicted from the velocity data and the smooth velocity curve using the Jarrard-Han porosity-velocity relationship (Davis and Villinger, 1992). Although considerable scatter exists in the measured porosities, the curve predicted from the velocity data represents the trend of the porosity measurements well, and this curve is used as a reference in the following discussion.

\section{Changes in Porosity and Velocity}

Figures 12 and 13 show porosity and velocity data from various holes in Middle Valley compared to the reference curves described above. The plots are ordered according to the degree of physical alteration observed. Highest porosities and lowest velocities were observed at Site 855 , the only site where the sediments are unlikely to have been subjected to high temperatures or hydrothermal fluid flow. The porosity data are scattered, but on average they follow the Cascadia reference curve. Velocities are more tightly clustered; they fall systematically below the reference curve, especially toward the bottom of the hole.

Porosities and velocities in the sediment column above the sill complex at Site 857 follow well-defined trends with depth, and both clearly diverge from the reference curves, even at depths as shallow as 50-100 mbsf; porosities are systematically low and velocities are systematically high. Within the sill complex, the data continue to diverge from the reference trends (see Fig. 8). Sediment porosities in that part of the section are consistently below $20 \%$, compared to normal values for this depth in the range of $35 \%-40 \%$. Velocities are highly scattered but typically fall between 3000 and $5000 \mathrm{~m} / \mathrm{s}$, well above the "normal" range of 2000-2200 m/s suggested by the reference curve. No abrupt change is apparent near the depth of the upper-most sill. Any influence of sill intrusion, if originally present, appears to have been completely overprinted by more pervasive hydrothermal alteration.

Close to the nearby Dead Dog vent field, sediments from Holes $858 \mathrm{~A}$ and $858 \mathrm{C}$ show signs of progressively greater alteration in terms of the rates at which porosity decreases and velocity increases with depth (Figs. 12 and 13). This progression culminates with the sediment beneath the vent field itself, at Holes $858 \mathrm{~B}, 858 \mathrm{D}$, and $858 \mathrm{~F}$. There, the sediments are physically fairly "normal" above the top of the hard sediment encountered at $32 \mathrm{mbsf}$ at $858 \mathrm{~B}$ and $29 \mathrm{mbsf}$ at $858 \mathrm{D}, 858 \mathrm{~F}$, and $858 \mathrm{G}$ (the transition being defined by the sudden decrease in the rate of penetration and failure of APC penetration). Below that depth, however, data are displaced well away from the reference curves. Porosities are as low as those in the sill complex and velocities are nearly as high, despite the much shallower depth of burial. An extreme degree of alteration is therefore implied.

Also illustrated in Figures 12 and 13 are data from Holes 856A and $856 \mathrm{~B}$. Hole $856 \mathrm{~A}$, located roughly $300 \mathrm{~m}$ from the discharge site that produced the Bent Hill massive sulfide deposit, shows signs of only minor alteration. The locally anomalous velocities within about $20 \mathrm{~m}$ of the bottom of that hole may be caused by alteration that accompanied the intrusion of the laccolith at this site. Sediments in Hole 856B are altered to a greater degree, particularly in the interval between a thin sill (less than $6 \mathrm{~m}$ thick) at $60 \mathrm{mbsf}$ and the top of the laccolith at 120 mbsf (see Fig. 13). The velocity profile in Hole $856 \mathrm{~B}$ is similar to that in Hole $858 \mathrm{C}$; these holes are similarly close to zones of previously and currently active hydrothermal upflow, respectively. The progressive alteration with depth and with proximity to the relic upflow zone in Holes $856 \mathrm{~A}$ and $856 \mathrm{~B}$ is consistent with the zonal character of chemical and mineralogical alteration seen in Holes 856A and 856B (Shipboard Scientific Party, 1992b; Goodfellow and Peter, this volume). All observations suggest that the general pattern of alteration in the holes did not originate from the intrusion of the laccolith or the thin sill; the alteration is best explained by the reaction of hydrothermal fluids with sediment around the periphery of the upflow zone that produced the Bent Hill sulfide deposit. The competence gained by the sediment through alteration may have provided the mechanical support for the thin sill encountered at $60 \mathrm{mbsf}$ (Fig. 13). 


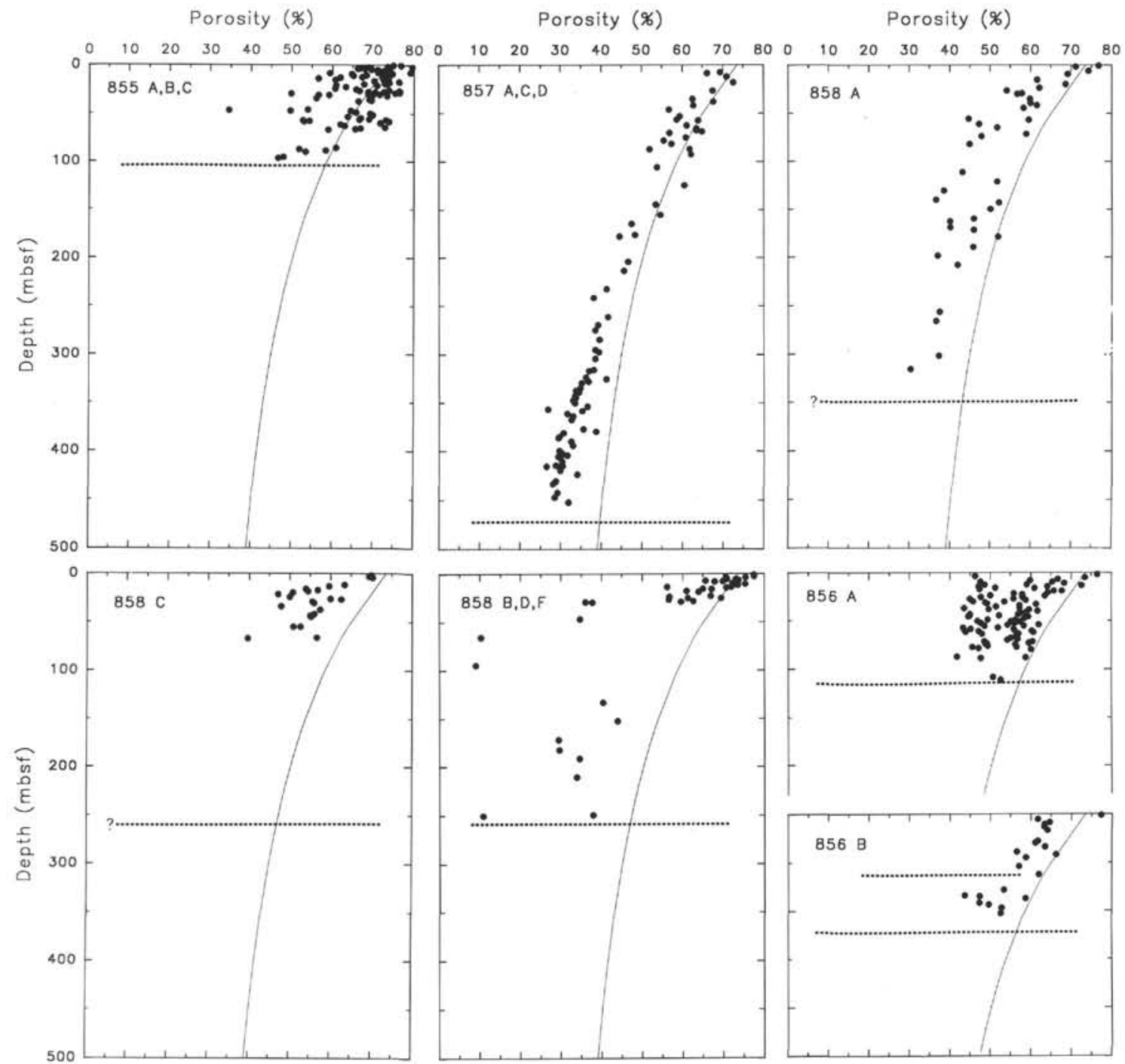

Figure 12. Porosity vs. depth for sediments of Leg 139 holes. Data are from Shipboard Scientific Party (1992a-d). Smooth curves from Cascadia Basin (Fig. 11) are shown for reference. Depths of igneous rock are shown by dashed lines. With the exception of those from Site 856, plots are ordered from lesser to greater degrees of alteration. Data from greater depths at Site 857 are shown in Figure 8.

The conclusion drawn from these observations, that hydrothermal alteration has had a major effect on the physical properties of the sediments, is stronger than that reached in the Initial Reports volume (Shipboard Scientific Party, 1992d), and by Rohr and Gröschel-Becker (this volume). According to the measurements on core samples, velocities at Site 857 are close to $1000 \mathrm{~m} / \mathrm{s}$ higher than those in the Cascadia Basin reference section at a depth of $450 \mathrm{mbsf}$, and over $1000 \mathrm{~m} / \mathrm{s}$ higher throughout the section (below $30 \mathrm{mbsf}$ ) at Site 858 .

An independent check on sediment velocities comes from the reflection times and drilling depths to basalt. These velocity estimates are shown in Figure 14, where they are compared to the running average velocities from the seafloor to depth calculated from the data shown in Figures 11 and 13. The reflection time at Site 855 is not well constrained because of the proximity to the fault (see Fig. 6). Furthermore, depths to basement at Holes $855 \mathrm{C}$ and $855 \mathrm{D}$ differ by $10 \%$, so there is considerable error associated with that velocity point; nevertheless, the agreement with the average velocity curve derived from the Middle Valley shipboard data and with the Cascadia reference curve is reasonable.

The point for Site 857 falls well above the velocity defined by the Cascadia curve, although it is below the average velocity line com- puted from the Middle Valley shipboard sample data. The latter difference may reflect seismic anisotropy: horizontal component data (Fig. 13) were used to compute the average velocity vs. depth curve, whereas the point computed from the reflection time is sensitive to the vertical component. Laboratory velocities determined under atmospheric conditions also may be erroneously low relative to those in situ (e.g., Gröschel-Becker et al., this volume).

Two points are shown for Site 858 . The lower velocity, which lies slightly below the Site 857 average velocity profile, was determined by the drilled depth to basement ( $258 \mathrm{mbsf}$ ) and the travel times to the isolated, bright reflector situated beneath the vent field at approximately $0.292 \mathrm{~s}$ (two-way time) below the seafloor (see Fig. 6). The higher velocity point, roughly $4000 \mathrm{~m} / \mathrm{s}$, was determined using the travel time to the local reflector at 0.129 s (Fig. 6; also see Fig. 9 of Rohr and Gröschel-Becker, this volume). Rohr and Gröschel-Becker interpret this earlier reflection as being from a sedimentary horizon. We favor an alternative explanation in which both reflections are from the top of the buried basement edifice, with the travel path for the earlier reflection through the anomalously fast sediment directly beneath the vent field, and the path for the later one being through the surrounding, more "normal" sediment section that is similar to the 

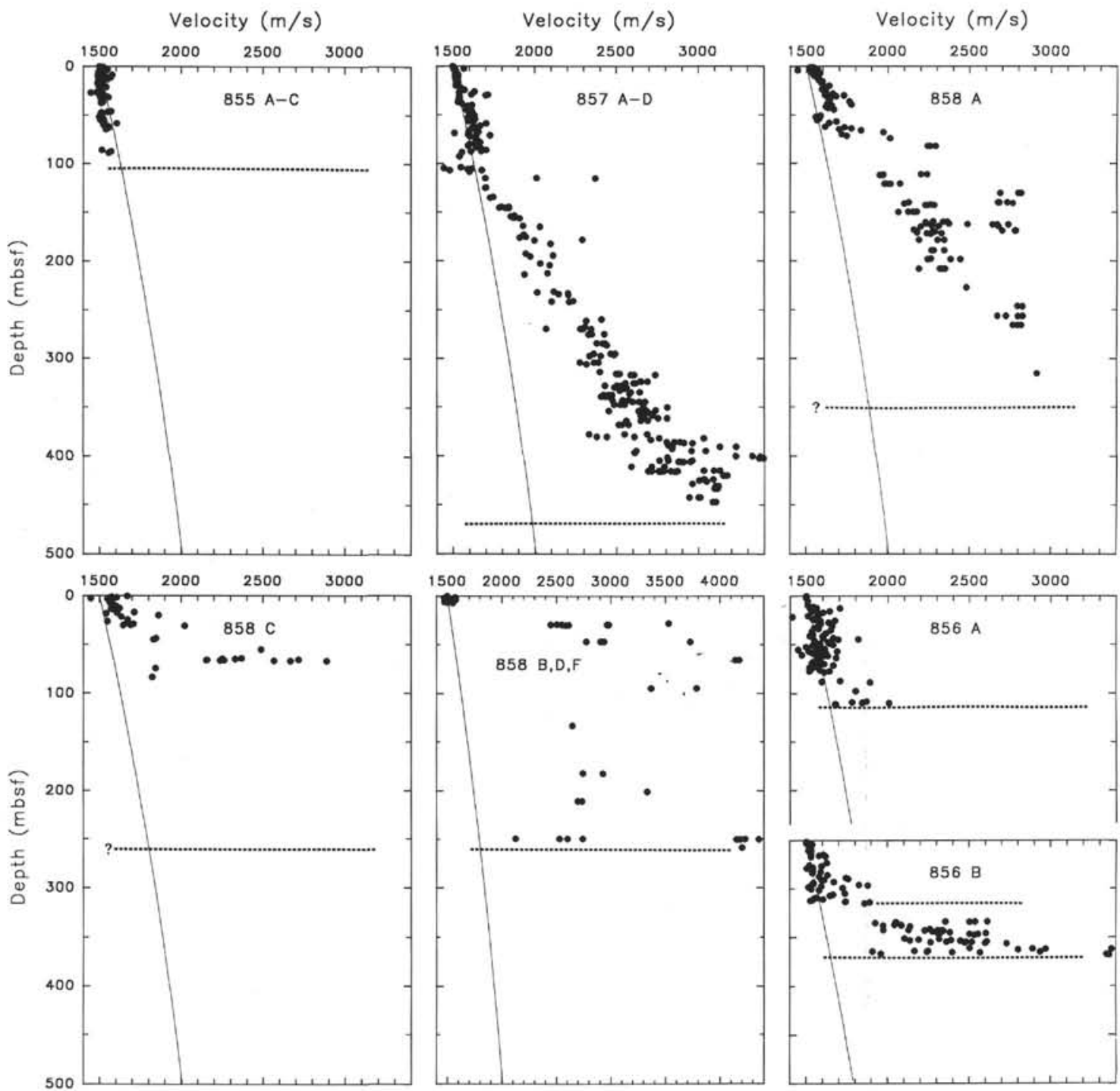

Figure 13. Velocity vs. depth for sediments of Leg 139 holes. Data are from Shipboard Scientific Party (1992a-d). Smooth curves from Cascadia Basin (Fig. 11) are shown for reference. Depths of igneous rock are shown by dashed lines. With the exception of those from Site 856, plots are ordered from lesser to greater degrees of alteration. Note change of velocity scale for Holes 858B, 858D, and 858F. Data from greater depths at Site 857 are shown in Figure 8.

section at Site 857 . The discrepancy between the velocity determined from the earlier reflection time and that determined from the shipboard sample data from Holes $858 \mathrm{~F}$ and $858 \mathrm{G}$ is large, much too large to be accounted for by the effects of anisotropy, although it may not be unreasonable, considering the large scatter in shipboard velocity determinations (Fig. 13) and the poor sample recovery (3\%). This interpretation requires the sample recovery to have been biased to low-velocity material. In normally consolidated sediments, there is a tendency for $\mathrm{RCB}$ coring to recover more competent (higher-velocity) material; lower-velocity material is probably more readily recovered in sections where brecciation, fracturing, veining, and hydrothermal silicification are common.

That the physical properties of the sediment are strongly affected by hydrothermal alteration is hardly a surprising result. What is remarkable, however, is that the velocity-porosity relationship followed during alteration (i.e., grain metamorphosis and cementation) is virtually indistinguishable from that followed during normal sediment compaction under low-temperature and low fluid-flux conditions. This is born out by the upper plot of Figure 15, which compares merged velocity and porosity data from Sites 857 and 858 to the velocity-porosity curve presented by Davis and Villinger (1992) de- rived from the data of Jarrard et al. (1989) and Han et al. (1986) from sections that have experienced burial consolidation, but not hydrothermal alteration. The agreement is excellent.

Merged sample data from Sites 855 and 856 are compared to the Jarrard-Han curve in the lower plot of Figure 15. Most of the porosity variations observed in the shallow holes at these sites were related to turbidite layering rather than to burial or hydrothermal consolidation and lithification. Porosity variations here are primarily associated with the contrast between low-porosity sandy basal turbidites and highporosity clay-rich interbeds; Hole $856 \mathrm{~A}$ was sampled specifically to examine these variations (Shipboard Scientific Party, 1992b). These porosity variations produce little velocity change, and the data fall well off the Jarrard-Han curve. Another explanation for this effect is that samples from Sites 855 and 856 are less hydrothermally altered, less competent, and therefore more subject to coring disturbance, although the coherency of the data supports the first explanation.

\section{Chemical Alteration of Sediments}

The chemical consequences of hydrothermal circulation are apparent in much of the shipboard geochemical data (Shipboard Scien- 


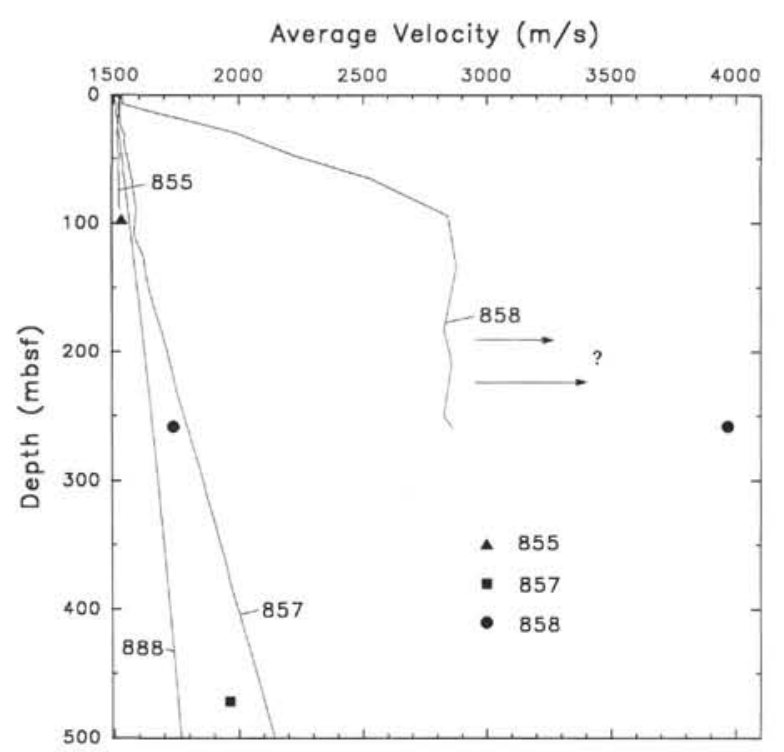

Figure 14. Average velocities to acoustic basement determined from the combination of seismic reflection travel times and drilled depths to basalt (points), compared to the average velocities computed from the velocity data shown in Figures 11 and 13 (solid lines).

tific Party, 1992a-d) and in many of the results presented in this volume (e.g., Buatier et al., this volume; Goodfellow and Peter, this volume; Zierenberg, this volume). Particularly revealing in the bulk geochemical data are the variations in concentrations of silica, which is added to the sediments during alteration as hydrothermal quartz, and of potassium, which is removed. Silica contents are shown in Figure 16 for the same suite of holes for which physical properties are shown in Figures 12 and 13.

Normal levels of $\mathrm{SiO}_{2}$ are assumed to be present at Site 855 . Values there range between $50 \%$ and $64 \% \mathrm{SiO}_{2}$ (by weight), with the mean falling at $56 \%$. Values at Site 857 above the first sill are similar (average $=56 \% \mathrm{SiO}_{2}$ ), as are values in Hole $858 \mathrm{~A}\left(\right.$ average $\left.=57 \% \mathrm{SiO}_{2}\right)$. Small anomalies are present in Holes 856A and 856B. A slight general enrichment in silica may be present in both holes; locally, low values associated with sulfidic zones can be seen in Hole 856B, as well as high values near the bottom of the hole. There are substantial changes in Holes $858 \mathrm{C}\left(61 \% \mathrm{SiO}_{2}\right.$ below $\left.25 \mathrm{mbsf}\right)$, Hole $858 \mathrm{~F}\left(62 \% \mathrm{SiO}_{2}\right.$ below $25 \mathrm{mbsf})$, and the deep part of Holes $857 \mathrm{C}$ and $858 \mathrm{D}\left(63 \% \mathrm{SiO}_{2}\right.$ below $470 \mathrm{mbsf}$ ). Mass balance calculations verify that these changes reflect the dumping of large amounts of hydrothermal silica in both the reservoir and upflow zones (Goodfellow and Peter, this volume).

Variations in potassium content demonstrate the effects of hydrothermal alteration even more clearly. These data (from Goodfellow and Peter, this volume), are shown in Figure 17. Values from Site 855 , Hole 856A, and from the upper part of the section at Site 857, cluster tightly around $2 \% \mathrm{~K}_{2} \mathrm{O}$. These values are probably representative of the potassium content of the unaltered sediment. Sediment in the vicinity of the Site 858 vent field (Holes $858 \mathrm{~A}$ and $858 \mathrm{C}$ ) and the fossil discharge zone at Site 856 (Hole 856B) display potassium enrichment in their upper parts and a general trend of depletion with depth. Potassium depletion is strong below $30 \mathrm{mbsf}$ in the upflow zone beneath the vent field (Holes 858B, 858D, and 858F), and sediments in hydrothermal basement at Site 857 are virtually completely depleted in $\mathrm{K}_{2} \mathrm{O}$. The transition at Site 857 from normal (c. $2 \% \mathrm{~K}_{2} \mathrm{O}$ ) to depleted values of $\mathrm{K}_{2} \mathrm{O}$ takes place between 425 and $450 \mathrm{mbsf}$, well above the top of the first sill, indicating that the sediments above the shallowest sill have been modified by, or have been part of, the permeable hydrothermal reservoir.
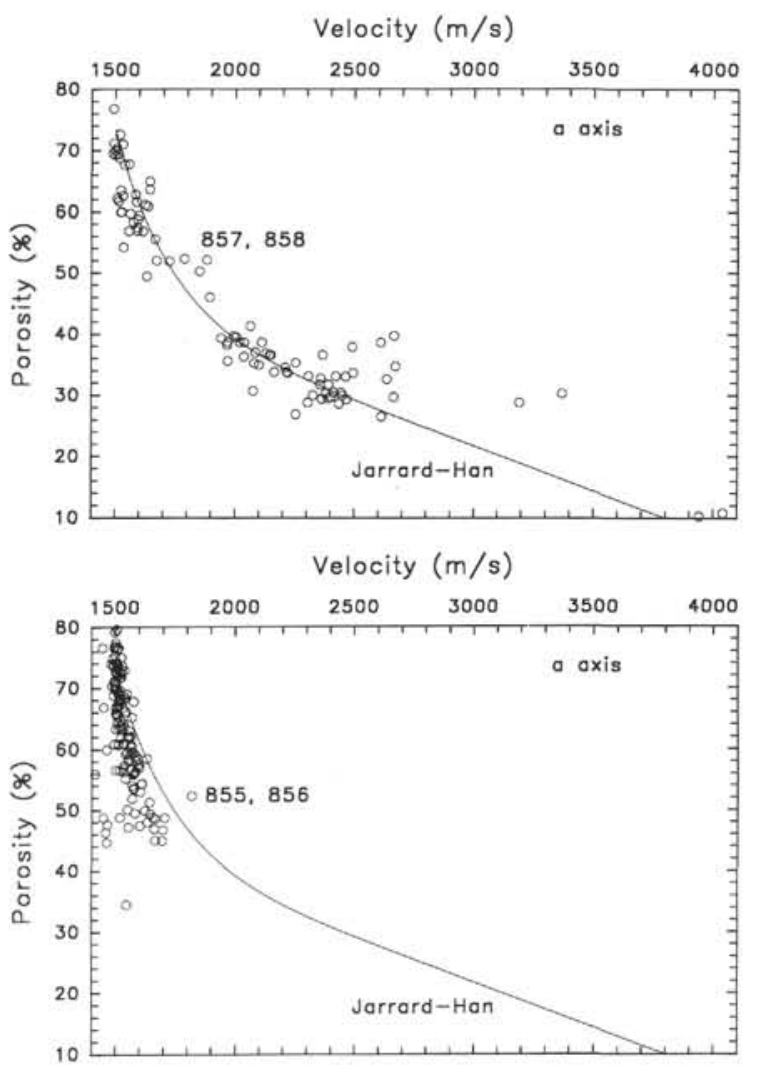

Figure 15 . Velocity vs. porosity for altered sediments at Sites 857 and 858 (upper plot) and for relatively unaltered sediments at Site 855 Hole $856 \mathrm{~A}$ (lower plot). Only data in which pairs of velocity and porosity measurements (Shipboard Scientific Party, 1992a-d) were made within $10 \mathrm{~cm}$ of one another are used. Solid lines show the relationship given by Davis and Villinger (1992) based on the data of Jarrard et al. (1989) and Han et al. (1986).

A lower limit for the water/rock ratio in the reservoir may be computed by assuming that the depletion in potassium, from $2 \%$ to zero $\mathrm{K}_{2} \mathrm{O}$, was accompanied by a change in water composition from seawater, at a concentration of roughly $10 \mathrm{mmol} / \mathrm{kg}$, to vent water at roughly $20 \mathrm{mmol} / \mathrm{kg}$ (see Butterfield et al., this volume). This requires a water/rock mass ratio of at least 50 . Keeping pace with a half-spreading rate of $27 \mathrm{~mm} / \mathrm{yr}$ would require a distributed fluid flux of $1.4 \mathrm{~m} / \mathrm{yr}$. Alteration of a 500 -m-thick section would require a fluid flux of 700 $\mathrm{m}^{3} / \mathrm{yr}$ per meter-length of the valley. If focused into a small area of discharge, as is currently the case at the Site 858 vent field, a high fluid flux is implied. For example, if the vent field served a region extending even as little as $5 \mathrm{~km}$ along the axis of the valley, an average discharge of $0.1 \mathrm{~m}^{3} / \mathrm{s}$ is implied. At least eight individual vents have been mapped in the field by camera tows and submersible observations and as many as 18 are inferred to be present on the basis of the acoustic imagery acquired over the field (Fig. 5; Shipboard Scientific Party, 1992c; Goodfellow and Franklin, in press). To make up the total flux, 20 vents would have to average $5 \mathrm{l} / \mathrm{s}$ of discharge each. At a discharge temperature of $280^{\circ} \mathrm{C}$, this would result in a long-term geothermal output of about $120 \mathrm{MW}$. This is roughly 50 times the present-day conductive heat flux through the seafloor in the vent-field area, but is small compared to the advective output of some seafloor hydrothermal fields (>1000 MW; e.g., Baker and Massoth, 1987; Rosenberg et al., 1988; Schultz et al., 1992; Thomson et al., 1992). Unfortunately, there is no good estimate available for the advective heat output of the Site 858 field. If the present-day discharge is less than $120 \mathrm{MW}$, then either the field was more vigorous in the past, or there were many more vent 


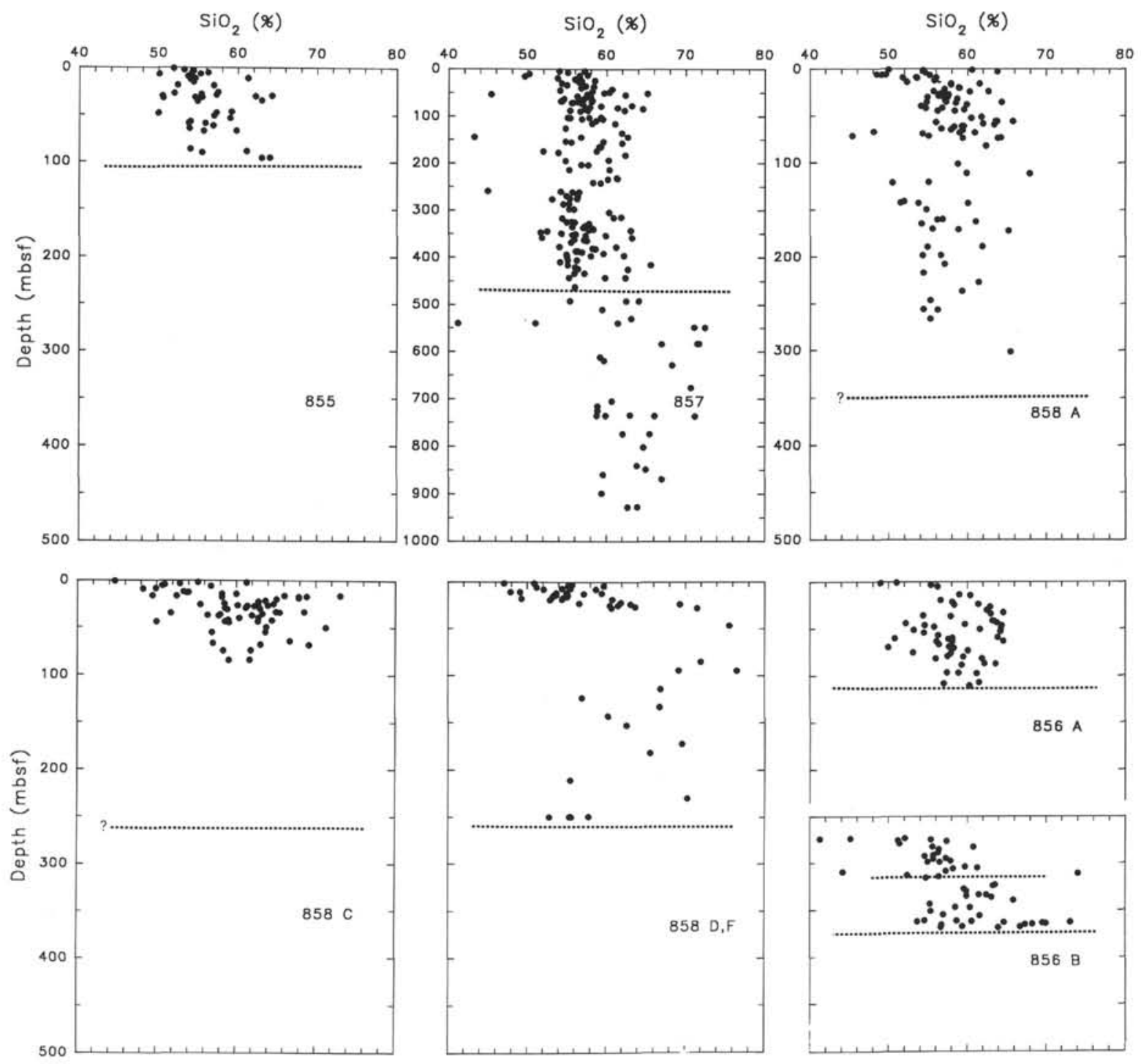

Figure 16. $\mathrm{SiO}_{2}$ contents of sediments from Leg 139 (Data from Goodfellow and Peter, this volume). Depths of igneous rock are shown by dashed lines. Plots are shown in the same order as those in Figures 12 and 13. Note different depth scale for Site 857.

fields active in the past expelling the hot water responsible for the alteration of the sediments in the hydrothermal basement reservoir.

\section{Sulfide Mineralization}

A mass- and heat-balance calculation can also be done using the estimated size and composition of the sulfide deposit sampled at Site 856. This calculation is similar to one done by Davis and Becker (in press) for a sulfide deposit in Escanaba Trough of the southern Gorda Ridge. The following assumptions and constraints are used in the present calculation: (1) the fluid that produced the deposit was saturated with iron at $500 \mathrm{ppm}$; (2) iron precipitated with $100 \%$ efficiency (an approximate upper limit); (3) the iron content in the deposit averages $60 \%$ (Goodfellow and Peter, this volume); (4) the sulfur content in the deposit is $35 \%$ (Goodfellow and Peter, this volume), of which half was supplied by basaltic source rocks (the other half is assumed to have been derived from reduced seawater sulfate, although there is considerable uncertainty regarding the partitioning of sources; see Duckworth et al., this volume; Zierenberg, this volume); (5) sulfur in the source rocks (basalt) was 0.1\% (Czamanske and Moore, 1977), and was completely removed by the hydrothermal fluid; (6) the temperature of the fluid was $400^{\circ} \mathrm{C}$ (Peter et al., this volume); and (7) the mass of the deposit is approximated by a cylinder of sulfide 100 $\mathrm{m}$ deep and $60 \mathrm{~m}$ in diameter with a density of $4000 \mathrm{~kg} / \mathrm{m}^{3}$ (Shipboard Scientific Party, $1992 \mathrm{~b}$; Tivey, this volume), totalling $10^{9} \mathrm{~kg}$. Calculations using these constraints yield the following results: (1) the volume of source rock required to provide sulfur for the deposit is modest, just over $70 \times 10^{6} \mathrm{~m}^{3} ;(2)$ the mass of water required to supply the iron in the deposit is $10^{12} \mathrm{~kg}\left(10^{9} \mathrm{~m}^{3}\right.$ at seafloor conditions); (3) this mass of water constrains the heat budget, and therefore the minimum volume of rock as a heat source. To heat this much water from zero to $400^{\circ} \mathrm{C}$ would require $400 \mathrm{~K} \times 4200 \mathrm{~J} / \mathrm{kg}-\mathrm{K} \times 10^{12} \mathrm{~kg}=1.7 \times 10^{18} \mathrm{~J}$. To supply this heat would require a volume of rock, solidifying and cooling from $1200^{\circ} \mathrm{C}$ to $400^{\circ} \mathrm{C}$, equal to $1.7 \times 10^{18} \mathrm{~J} /\left\{\left(320 \times 10^{3} \mathrm{~J} / \mathrm{kg} \times\right.\right.$ $\left.\left.2800 \mathrm{~kg} / \mathrm{m}^{3}\right)+\left(800 \mathrm{~K} \times 1000 \mathrm{~J} / \mathrm{kg}-\mathrm{K} \times 2800 \mathrm{~kg} / \mathrm{m}^{3}\right)\right\}=500 \times 10^{6}$ $\mathrm{m}^{3}$, equivalent to a cube $800 \mathrm{~m}$ on a side. This is roughly 10 times the volume needed to supply the mass of sulfur for this 1 million tonne deposit, and probably many times the volume of the laccolith, but a 


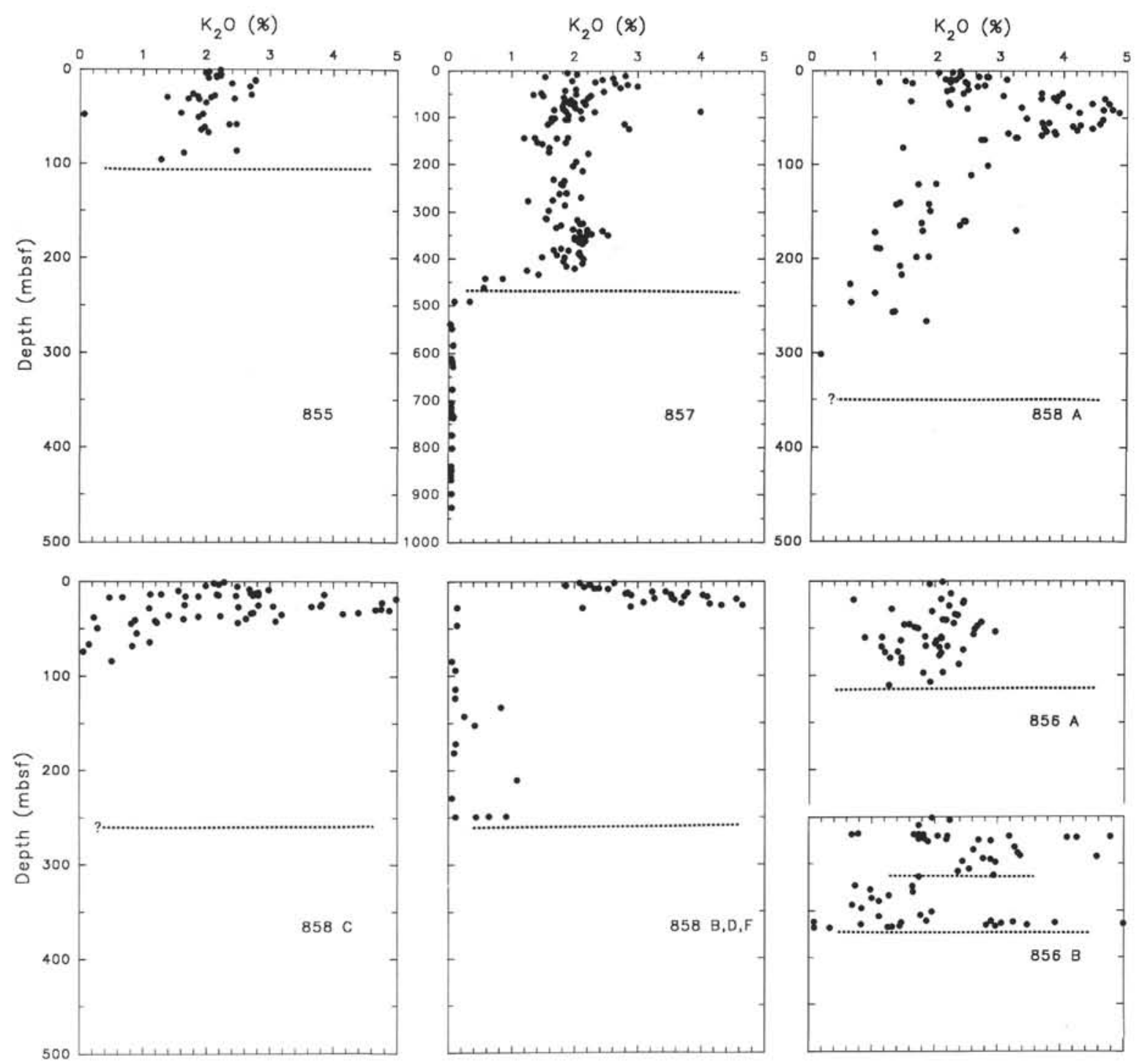

Figure 17. $\mathrm{K}_{2} \mathrm{O}$ contents of sediments from Leg 139 (Data from Goodfellow and Peter, this volume). Depths of igneous rock are shown by dashed lines. Plots are shown in the same order as those in Figures 12, 13, and 16. Note different depth scale for Site 857.

volume of this magnitude is still not too large to be accounted for with a local intrusive heat source beneath the Bent Hill deposit (see Fig. 1). A regional or remote source is not required.

\section{DISCUSSION}

\section{General Implications for Fluid Circulation}

The inferences and semiquantitative estimates regarding hydrothermal circulation in Middle Valley given above are crude and must be considered with caution. Nevertheless, drilling during Leg 139 has clearly provided many new insights into the hydrothermal system in this sedimented rift and has led to several fundamental conclusions about the effectiveness of the turbidite fill of the valley in restricting hydrothermal flow, the presence and nature of hydrothermal basement, the forces that drive fluids through basement and up through the sediment section where isolated permeable pathways exist or are created, and the effect that hydrothermal circulation has on the physical properties and chemical composition of rocks through which they pass. Of particular interest are some of the more specific conclusions concerning the role of the hydrothermal reservoir beneath the sediment seal in the production of massive sulfide deposits in these settings, conclusions that might extend to modern hydrothermal sys- tems in sediment-free ridge-crest settings, and to their ancient analogs. These conclusions are reached by considering a few key aspects of Sites 857,858 , and 856.

Hydrologically, striking similarities exist between Sites 858 and 856. As discussed above and in papers throughout this volume, the fluid upflow zones beneath both Sites 856 and 858 are hydrologically isolated from the sediments that surround them. Lateral thermal gradients at the sites are high (Davis and Villinger, 1992; Shipboard Scientific Party, 1992b, 1992d). Thermal measurements in holes as close as $50 \mathrm{~m}$ from discharge sites require only conductive heat transport (Fig. 9 ), indicating that present-day fluid flow at thermally significant rates is limited to relatively narrow zones at both sites. Rapid fluid flow also was likely to have been isolated in the past at both sites, as indicated by the high physical and chemical alteration gradients in sediments adjacent to the upflow zone at Site 858 and adjacent to the sulfide deposit at Site 856 (Figs. 12, 13, 16, and 17; Goodfellow and Peter, this volume). Fine-grained sediments from both sites are relatively impermeable (Fisher et al., this volume) compared to the underlying basement (Becker et al., this volume; Bessler et al., this volume), and compared to the extrusive edifice, sediments, or sulfides in the upflow zones themselves (Shipboard Scientific Party, 1992b, 1992d; Davis and Becker, this volume). This contrast in permeability provides a sim- 
ple means of focusing fluid flow through the sediment section. The relatively high permeabilities in the upflow zones are probably associated with open fractures, which in the case of the sediments, may be supported by the strength given to the rock by the high degree of alteration and maintained by hydrofracturing and tectonic activity. Faulting might also play a role in creating fluid pathways at depth (Goodfellow and Franklin, in press), although this association has not been documented in the case of either Site 858 or 856 , as faults are not observed extending along strike from these sites in seismic reflection profiles. There also may be similarities in the origin of forces driving upflow currently at Site 858 , in the past at Site 856 , and currently at the vent south of Site 856 . The simple "choked-chimney" mechanism outlined by Davis and Becker (this volume) is probably applicable in all instances.

Here similarities probably end, however, and the differences outlined below lead to the conclusion that Sites 856 and 858 are genetically distinct. The large sulfide deposit at Site 856 probably was created by a hydrothermal system that was not fundamentally linked to the regional system characterized by Sites 857 and 858 .

The most obvious difference is in the contrasting hydrothermal temperatures observed at the two sites. Temperatures of the hydrothermal fluids that produced the massive sulfide deposit at Site 856 were high, probably close to $400^{\circ} \mathrm{C}$ (Leybourne and Goodfellow, this volume; Peter et al., this volume). In contrast, there is no evidence that hydrothermal temperatures were ever this high at Site 858. Current temperatures of hydrothermal vents at Site 858 range up to $276^{\circ} \mathrm{C}$ (Shipboard Scientific Party, 1992d; Goodfellow and Franklin, in press), and temperatures estimated in the associated upflow zone are similar, in the neighborhood of $280^{\circ} \mathrm{C}$ (Shipboard Scientific Party, 1992d; Langseth and Becker, this volume). No significant accumulations of high-temperature sulfide minerals were encountered at Site 858 , or observed by submersible mapping (Goodfellow and Franklin, in press), and it is unlikely that any significant accumulations are present that have not been sampled (Nobes et al., 1992; Tivey, this volume). Alteration mineralogy and fluid inclusion data from the upflow zone suggest temperatures ranging from 250 to $300^{\circ} \mathrm{C}$, which bracket the current hydrothermal temperatures (Goodfellow and Peter, this volume; Leybourne and Goodfellow, this volume; Peter et al., this volume). Thus, it appears unlikely that the hydrothermal discharge at Site 858 is an analog of the relic system at Site 856 , simply in a different phase of activity.

There also seem to be major differences in the nature of the primary reaction zones that supply and supplied fluids to the discharge zones at Sites 858 and 856 , respectively. It is well demonstrated that discharge at Site 858 derives fluid from the regional hydrothermal basement reservoir drilled at Site 857 . This has been established on the basis of (1) similarities in the temperatures estimated in hydrothermal basement regionally and at Site 857 specifically (Davis and Villinger, 1992; Davis and Wang, this volume; Langseth and Becker, this volume; Villinger et al., this volume), and temperatures estimated in the upflow zone and measured at seafloor vents at Site 858 (Shipboard Scientific Party, 1992b, 1992d; Goodfellow and Franklin, in press); (2) mineralogical and chemical similarities of altered sediment in the upflow zone at Site 858 and in hydrothermal basement at Site 857 (Goodfellow and Peter, this volume; Leybourne and Goodfellow, this volume); (3) compositional similarities between basement fluids at Site 857 and vent fluids at Site 858 (Shipboard Scientific Party, 1992c, 1992D; Butterfield et al., this volume); and (4) inferences derived from hydrologic observations (Becker et al., this volume; Davis and Becker, this volume). Based on the reasonably narrow range of temperatures experienced by the sediments at both sites (Leybourne and Goodfellow, this volume; Peter et al., this volume), it is reasonable to conclude that present hydrothermal conditions have persisted for much of the history of hydrothermal discharge at Site 858. This uniform history suggests that temperatures in the regional hydrothermal basement reservoir have been buffered by vigorous hydrothermal circulation that has efficiently distributed the spatially and temporally variable heat supplied from the cooling of sills and deeper intrusive bodies. The average level of temperature may have been set by the balance between the heat supplied by the intrusions and the heat lost conductively to and through the sediments deposited in the valley.

In contrast to the simplicity of the system characterized by Sites 857 and 858 , the hydrothermal system that produced the sulfide mineral deposit at Bent Hill was complex in terms of its geometry and history. Compositional variations and mineralogical relationships within the deposit indicate that the composition and temperature of fluids that produced and later modified the deposit varied significantly through the history of sulfide deposition. This is evident in a major overprinting of the primary pyrrhotite-wurtzite-isocubanite mineral assemblages by pyrite-magnetite (Shipboard Scientific Party, 1992b; Duckworth et al., this volume; Krasnov et al., this volume), infilling of voids with magnesium-rich silicates and carbonates (Shipboard Scientific Party, 1992b; Duckworth et al., this volume), and fluid inclusions in the secondary quartz and carbonate that yield compositions and temperatures similar to fluids currently venting from the regional reservoir. The temperature and composition of the fluids that produced the primary sulfide minerals were clearly distinct from those of the regional reservoir, and the fluids probably followed a complex pathway. The products of hydrothermal discharge at Site 856 suggest that at least two sources of water were involved. Although the temperature of the fluid that produced the primary sulfide minerals was high, relatively low concentrations of $\mathrm{Pb}, \mathrm{As}$, and $\mathrm{Sb}$ (elements that are enriched in sediment-hosted sulfide deposits; e.g., Koski et al., 1988) precludes interaction of fluids with sediment at high temperature $\left(350-400^{\circ} \mathrm{C}\right)$ (Shipboard Scientific Party, 1992d). The primary reaction zone for metals thus appears to have been situated below the sediment-sill complex, within the purely igneous part of the upper oceanic crust. $\mathrm{Pb}, \mathrm{Sr}, \mathrm{He}$, and particularly $\mathrm{S}$ isotope systematics all suggest that sediments did contribute to the composition of the fluids, however (Duckworth et al., this volume; Stuart et al., this volume; Zierenberg, this volume; Goodfellow and Franklin, in press). The means by which the hybrid fluids were created is not clear. Goodfellow and Peter (this volume) and Duckworth et al. (this volume) suggest that fluids from the primary (high-temperature, pure-basalt) reaction zone mixed with fluids from hydrothermal basement (the sediment-sill complex) to produce the hydrothermal fluids that formed the seafloor deposit. A hydrologically simpler situation would be one in which fluids were supplied to the high-temperature reaction zone from the regional hydrothermal basement reservoir.

In conclusion, it appears that the conditions that produced the large massive sulfide deposit at Site 856 must be relatively rare, and perhaps similar to those associated with the formation of large deposits on unsedimented ridges. The biggest difference may be that the fluids supplied to the high-temperature reaction zone at Site 856 were pre-heated to $280^{\circ} \mathrm{C}$ and had reacted with sediment at that temperature. Presumably because of (1) the limits on heat supply imposed by the spreading rate and the depth to which hydrothermal circulation can derive heat, and (2) the rate of heat loss determined by the average sediment thickness, high temperatures cannot be maintained regionally. A similar conclusion was reached by Davis and Becker (in press) on the basis of heat flow and seismic reflection data in Escanaba Trough. There, temperatures estimated in basement regionally are only about $100^{\circ} \mathrm{C}$, and as in Middle Valley, hydrothermal systems of sufficiently high temperature to produce major sulfide deposits appear to be relatively rare and localized.

\section{Recommendations for Further Studies and Future Drilling}

Although Leg 139 was a great scientific and operational success, several critical hydrogeologic questions remain incompletely answered or unanswered. These questions relate to (1) the physical and chemical state of the oceanic crust, (2) the driving forces for hydrothermal con- 
vection, and (3) the relationships between apparently discrete phases and components of hydrothermal activity. Related questions in each of these areas are explored below.

What has been the quantitative influence of hydrothermal circulation on the chemical and physical properties of sediments and basalt within the upper $1000 \mathrm{~m}$ of crust? Addressing this question would require comparison with an unaltered site (i.e., the drilling of a deep reference hole in an area of low heat flow, with coring and a complete suite of logs run in the open hole). This reference site must be located in an area with a thick sediment section. It would be particularly valuable to obtain a full set of measurements with the geochemical logging string at such a site, as these data would be useful for calculating total geochemical fluxes (through comparison with more altered sites). Other useful logs would be those providing in-situ porosity and velocity information, so that constitutive relationships could be developed for the unaltered section. Major uncertainties with quantitative analysis of $\log$ and laboratory data from the Leg 139 sites are associated with separating the effects of ordinary compaction from those of hydrothermal alteration. Site 855 was originally intended to be a reference site, but the section of sediments overlying basement there was not adequately thick. Site 857 thus became a de-facto reference site for Leg 139, but even in the upper few hundred meters of the sediment section, significant signs of alteration are present (Fig. 8).

What is the present temperature structure in the deeper part of the sediment section and within hydrothermal basement in Middle Valley? Shallow temperature measurements were remarkably successful during Leg 139, providing a reliable and consistent set of heat flow determinations that correlate well with seafloor survey data. Numerous logging tools run deep in holes at Sites 857 and 858 also performed well, but major perturbations from drilling disturbances and from downhole flow of cold seawater prevented accurate formation temperatures from being determined. One approach for getting deeper temperature measurements that was partly successful during Leg 139 was to drill and case, but not to immediately drill out, deep holes. Temperature logs run in these temporarily "closed" holes, following several days of thermal equilibration, were revealing, but even allowing this much time, they were insufficient for the drilling disturbances to decay. Repeat logs therefore are necessary for this operation. CORK instrumentation also provides a means to determine undisturbed formation temperatures, or in some cases long-term temperature variations.

The "isothermal" hydrothermal basement reservoir model discussed throughout this volume (e.g., Bessler et al., this volume; Davis and Wang, this volume; Villinger et al., this volume) is consistent with the observations from Leg 139 (e.g., Peter et al., this volume). The degree of isothermality, the amplitude of pressure variations, and the thickness of this permeable zone are undetermined, however, and require further investigation. Replacement of the short thermistor string hanging below the CORK in Hole $857 \mathrm{D}$ will help to address this problem. Deeper penetration and a time series of measurements within another deep hole also would be valuable.

What are the lateral and vertical variations in pore fluid pressures in and near zones of hydrothermal upflow? Is the "choked chimney" model for Site 858 and other similar sites reasonable? Do conditions exist locally or episodically that cause draw-down of seawater in the sediments that surround upflow zones, as suggested by the locally high $\mathrm{Mg}$ concentrations in the sediments surrounding the cores of the upflow zones at Sites 856 and 858 (Shipboard Scientific Party, 1992c, 1992d; Goodfellow and Peter, this volume)? Since fluid will flow along the path of least resistance and greatest pressure drop, it is not possible to use inferred fluid flow directions or velocities alone to calculate the piezometric surface below the seafloor at Middle Valley. Nor can pore pressures alone be used to infer present fluid velocities or directions. In combination with flow velocity and direction information inferred from thermal and chemical data, however, pore pressure information can be used to constrain the effective permeability structure of the hydrothermal system. Ideally, pressure measurements would be made over a broad zone within the shallow sediments around the active seafloor sites. Determining the nature of deeper pore pressure gradients will require installation of one or more transects of instrumented, sealed boreholes, either with existing CORK instrumentation, or with less expensive hydrologic monitoring instruments that can be deployed in non-reentry holes. Clearly, care must be used in the completion of holes; lessons must be learned, for example, from the long-term disturbance caused by the presence of exploratory Hole 858F (Davis and Becker, this volume).

What is the nature of permeability in hydrothermal basement and in hydrothermal upflow zones? How important are faults such as those inferred to have been intersected at Site 857 ? How well are major permeable zones connected to one another and to the bulk of the formation, and how are the "average" formation properties defined? Direct observations at a variety of scales are required to address these questions, perhaps including multihole injection tests and more detailed permeability "logs" carried out with an intermediate-scale straddle-packer or with an injection flow-meter like that used during Leg 139 (Becker et al., this volume). Detailed imagery, acquired with tools such as the borehole televiewer and the formation microscanner, and detailed geochemical logs, would also provide valuable new information.

Clearly one of the greatest opportunities in Middle Valley is to better understand the formational history of the large massive sulfide deposit at Site 856 . From a hydrogeologic standpoint, it would be helpful to know the true lateral and vertical extent of the deposit, as this would help to constrain chemical and heat budgets for the relic hydrothermal system that formed it. It also would be useful to have better constraints on the lifetime of high-temperature discharge and on the influence of hydrothermal activity at Site 856 on the regional hydrothermal reservoir. Was high-temperature upflow through the uppermost crust hydrologically isolated, as it was through the sediment section, or was there significant interaction with the cooler reservoir fluids? What was the predominant direction of lateral flow, and how did it vary with depth and/or time? What was the nature of permeability in the feeder zone beneath the deposit? Most of these questions can be addressed with a transect of holes radiating from the Site 856 deposit, with penetration extending through the surrounding sediments and tens of meters into basement. To attempt to penetrate the feeder zone will require one of these to be a deep reentry hole. The transect should avoid the complications of the laccolithic intrusion beneath Bent Hill.

The operational successes of Leg 139 suggest that all of the above goals can be well met with the careful use of existing drilling, logging, and downhole technology.

\section{ACKNOWLEDGMENTS}

The authors extend their appreciation to other members of the Shipboard Scientific Party for the energy they devoted to this project, both during and after the drilling leg. The project benefited greatly from the generous support of the Ocean Drilling Program, which went well beyond the call of duty to ensure the safety and success of the unusual aspects of the leg. K. Wang provided the numerical model used for the results shown in Figures 7 and 9. Critical reviews and helpful comments were provided by J. Slack, W. Goodfellow, M. Mottl, J. Morton, and D. Chapman. GSC contribution no. 33993.

\section{REFERENCES}

Baker, E.T., and Massoth, G.J., 1987. Characteristics of hydrothermal plumes from two vent fields on the Juan de Fuca Ridge, northeast Pacific Ocean. Earth Planet. Sci. Lett., 85:59-73.

\footnotetext{
-Abbreviations for names of organizations and publications in ODP reference lists follow the style given in Chemical Abstracts Service Source Index (published by American Chemical Society).
} 
Curray, J.R., Moore, D.G., et al., 1982. Init. Repts. DSDP, 64 (Pts. 1 and 2): Washington (U.S. Govt. Printing Office).

Curray, J.R., Moore, D.G., Lawver, L.A., Emmel, F.J., Raitt, R.W., Henry, M., and Kieckhefer, R., 1978. Tectonics of the Andaman Sea and Burma. AAPG Mem., 29:189-198.

Currie, R.G., Davis, E.E., Riddihough, R.P., and Sawyer, B.S., 1985. Juan de Fuca Ridge Atlas: preliminary Sea Beam bathymetry. Geol. Surv. Can. Open File, 1143.

Czamanske, G.K., and Moore, J.G., 1977. Composition and phase chemistry of sulfide globules in basalt from the Mid-Atlantic Ridge rift valley near $37^{\circ} \mathrm{N}$ lat. Geol. Soc. Am. Bull., 88:587-599.

Davis, E.E., and Becker, K., in press. Thermal and tectonic structure of the Escanaba Trough: new heat-flow measurements and seismic reflection profiles. In Morton, J.L., Zierenberg, R.A., and Reiss, C.A., Geologic, Hydrothermal, and Biologic Studies at Escanaba Trough, Gorda Ridge, Offshore Northern California. U.S. Geol. Surv. Bull., 2022.

Davis, E.E., Chapman, D.S., Forster, C.B., and Villinger, H., 1989. Heat-flow variations correlated with buried basement topography on the Juan de Fuca Ridge flank. Nature, 342:533-537.

Davis, E.E., Chapman, D.S., Mottl, M.J., Bentkowski, W.J., Dadey, K., Forster, C., Harris, R., Nagihara, S., Rohr, K., Wheat, G., and Whiticar, M., 1992. FlankFlux: an experiment to study the nature of hydrothermal circulation in young oceanic crust. Can. J. Earth Sci., 29:925-952.

Davis, E.E., and Currie, R.G., 1993. Geophysical observations of the northern Juan de Fuca Ridge system: lessons in sea-floor spreading. Can. J. Earth Sci., 30:278-300.

Davis, E.E., Currie, R.G., and Sawyer, B.S., 1987. Marine geophysical maps of western Canada: regional SeaMARC II acoustic image mosaics and Sea Beam bathymetry. Geol. Surv. Can., Maps 2-1987 to 17-1987.

Davis, E.E., Goodfellow, W.D., Bornhold, B.D., Adshead, J., Blaise, B., Villinger, H., and Le Cheminant, G.M., 1987. Massive sulfides in a sedimented rift valley, northern Juan de Fuca Ridge. Earth Planet. Sci. Lett., 82:49-61.

Davis, E.E., and Lister, C.R.B., 1977. Heat flow measured over the northern Juan de Fuca Ridge: evidence for widespread hydrothermal circulation in a highly heat-transportive crust. J. Geophys. Res., 83:4845-4860.

Davis, E.E., Mottl, M.J., Fisher, A.T., et al., 1992. Proc. ODP, Init. Repts., 139: College Station, TX (Ocean Drilling Program).

Davis, E.E., and Villinger, H., 1992. Tectonic and thermal structure of the Middle Valley sedimented rift, northern Juan de Fuca Ridge. In Davis, E.E., Mottl, M.J., Fisher, A.T., et al., Proc. ODP, Init. Repts., 139: College Station, TX (Ocean Drilling Program), 9-41.

Denlinger, P., and Holmes, M.L., in press. Thermal and mechanical models for sediment hills and associated sulfide deposits along the Escanaba Trough. In Morton, J.L., Zierenberg, R.A., and Reiss, C.A. (Eds.), Geologic, Hydrothermal, and Biologic Studies at Escanaba Trough, Gorda Ridge, Offshore Northern California. U.S. Geol. Surv. Bull., 2022

Fisher, A.T., and Becker, K., in press. Heat flow, hydrothermal circulation, and basalt intrusions in the Guaymas Basin, Gulf of California. Earth Planet. Sci. Lett.

Goodfellow, W.D., and Franklin, J.M., in press. Geology, mineralogy and geochemistry of massive sulfides in shallow cores, Middle Valley, Northern Juan de Fuca Ridge. Econ. Geol.

Han, D., Nur, A., and Morgan, D., 1986. Effects of porosity and clay content on wave velocities in sandstones. Geophysics, 51:2093-2107.

Jarrard, R.D., Dadey, K.A., and Busch, W.H., 1989. Velocity and density of sediments of Eirik Ridge, Labrador Sea: control by porosity and mineralogy. In Srivastava, S.P., Arthur, M.A., Clement, B., et al., Proc. ODP, Sci. Results, 105: College Station, TX (Ocean Drilling Program), 811-835.
Koski, R.A., Shanks, W.C., III, Bohrson, W.A., and Oscarson, R.L., 1988. The composition of massive sulfide deposits from the sediment-covered floor of Escanaba Trough, Gorda Ridge: implications for depositional processes. Can. Mineral., 26:655-673.

Larson, P.A., Mudie, J.D., and Larson, R.L., 1972. Magnetic anomalies and fracture trends in the Gulf of California. Geol. Soc. Am. Bull., 83:33613368.

Nobes, D.C., Law, L.K., and Edwards, R.N., 1992. Results of a seafloor electromagnetic survey over a sedimented hydrothermal area on the Juan de Fuca Ridge. Geophys. J. Int., 110:333-346.

Rohr, K.M., Davis, E.E., and Hyndman, R.D., 1992. Multi-channel seismic reflection profiles across Middle Valley, northern Juan de Fuca Ridge. Open-File Rep.-Geol. Surv. Can., 2476.

Rosenberg, N.D., Lupton, J.E., Kadko, D., Collier, R., Lilley, M.D., and Pak, H., 1988. Estimation of heat and chemical fluxes from a seafloor hydrothermal vent field using radon measurements. Nature, 334:604-607.

Schultz, A., Delaney, J.R., and McDuff, R.E., 1992. On the partitioning of heat flux between diffuse and point-source seafloor venting. J. Geophys. Res., 97:12299-12314.

Shipboard Scientific Party, 1992a. Site 855. In Davis, E.E., Mottl, M.J., Fisher, A.T., et al., Proc. ODP, Init. Repts., 139: College Station, TX (Ocean Drilling Program), 101-160.

1992b. Site 856. In Davis, E.E., Mottl, M.J., Fisher, A.T., et al., Proc. ODP, Init. Repts., 139: College Station, TX (Ocean Drilling Program), 161-281.

, 1992c. Site 857. In Davis, E.E., Mottl, M.J., Fisher, A.T., et al., Proc. ODP, Init. Repts., 139: College Station, TX (Ocean Drilling Program), 283-429.

1992d. Site 858. In Davis, E.E., Mottl, M.J., Fisher, A.T., et al., Proc. ODP, Init. Repts., 139: College Station, TX (Ocean Drilling Program), 431-569.

, in press. Site 888. In Westbrook, G.K., Carson, B., Musgrave, R.J., et al., Proc. ODP, Init. Repts., 146 (Pt. 1): College Station, TX (Ocean Drilling Program).

Spell, T.L., and McDougall, I., 1992. Revisions to the age of the BrunhesMauyama boundary and the Pleistocene geomagnetic time scale. Geophys. Res. Lett., 19:1181-1184.

Tamaki, K., Pisciotto, K., Allan, J., et al., 1990. Proc. ODP, Init. Repts., 127: College Station, TX (Ocean Drilling Program).

Thomson, R.E., Delaney, J.R., McDuff, R.E., Janecky, D.R., and McClain, J.S., 1992. Physical characteristics of the Endeavour Ridge hydrothermal plume during July 1988. Earth Planet. Sci. Lett., 111:141-154.

Yuan, T., Spence, G.D., and Hyndman, R.D., 1994. Seismic velocities and inferred porosities in the accretionary wedge sediments at the Cascadia Margin. J. Geophys. Res., 99:4413-4427.

Zierenberg, R.A., Morton, J.L., Koski, R.A., and Ross, S.L., in press. Geologic setting of massive sulfide mineralization in Escanaba Trough. In Morton, J.L., Zierenberg, R.A, and Reiss, C.A. (Eds.), Geologic, Hydrothermal, and Biological Studies at Escanaba Trough, Gorda Ridge, Offshore California. U.S. Geol. Surv. Bull., 2022.

Date of initial receipt: 8 September 1993

Date of acceptance: 22 November 1993

Ms 139SR-259 